\title{
Petrographic characteristics and paleomires of Mand-Raigarh coals, Mahanadi Gondwana Basin, Chhattisgarh, India
}

\author{
A. S. Naik ${ }^{1}$ M. P. Singh ${ }^{1}$ N. Volkmann ${ }^{2}$ P. K. Singh ${ }^{1} \cdot$ D. Mohanty ${ }^{3}$ D. Kumar ${ }^{1}$
}

Received: 29 December 2015/Revised: 23 February 2016/ Accepted: 29 March 2016/Published online: 8 July 2016

(C) The Author(s) 2016. This article is published with open access at Springerlink.com

\begin{abstract}
Mand-Raigarh coalfield is one of the largest coalfields in the Mahanadi basin. The Geological Survey of India carried out initial study primarily on exploration. However, detailed petrographic and geochemical characters of the coals have not been done so far. This investigation is an attempt for petrographic and geochemical appraisal of the coals. Moreover, effort is also made for possible interpretation on development of coal facies. The results drawn from 30 composite coal samples suggest coals are rich in vitrinite, with collotelinite as the dominant maceral while liptinite macerals register low concentration. Dominant mineral assemblages found were clay minerals, pyrite was recorded as disseminated, framboidal and euhedral forms, carbonates recorded were mainly siderites. The vitrinite reflectance random (VRo) mean values range from $0.44 \%$ to $0.56 \%$, and the rank of coal is suggested as high volatile 'B' to 'A' subbituminous in rank. The rock-eval pyrolysis reveal TOC content varying from $37 \%$ to $68.83 \%$, while low hydrocarbon generating potential is evident from low S2 and $T_{\max }$ values. The Hydrogen Index (HI) versus Oxygen Index (OI) plot reveal that the samples belong to Kerogen type-II-III with input dominantly from terrestrial source, some samples also fall in Kerogen type-II domain indicating lacustrine input. Vitrinite reflectance result indicate that the samples are immature and approaching oil window, which is in agreement with data of the Rock-Eval parameters. The gelification index (GI) and tissue preservation index (TPI) indicate that the coal developed in a telematic set up with high tree density. The ground water index (GWI) and vegetation index (VI) demonstrate that the peat developed as an ombrogenous bog.
\end{abstract}

Keywords Mand-Raigarh coalfield $\cdot$ Organic petrology $\cdot$ Geochemistry $\cdot$ Source rock

\section{Introduction}

Energy management is an important agenda of an economic planning especially in a country like India where hydrocarbon resources are very limited giving rise to an ever increasing oil pool deficit. Fortunately, India has substantial reserves of coal deposits, 4th largest in the

\footnotetext{
A. S. Naik

amiyanaik@yahoo.co.in

Banaras Hindu University, Varanasi, India

T U Bergakademie, Freiberg, Germany

3 CSIR-Central Institute of Mining and Fuel Research, Dhanbad, India
}

world (Ministry of Coal 2015) and therefore, it has served as the backbone of the energy mix in India. In the present scenario about $58 \%$ of the electricity is generated from the coalfired boilers (Ministry of Power 2014). With nearly $99 \%$ of the reserves (Acharya 2000; Dasgupta 2006; Mukhopadhyay et al. 2010) hosted in the Gondwana Basins, study and development of these resources is of utmost importance for the sustainance of the economic growth of the country. Mand-Raigarh coalfield (Fig. 1) is one of the largest coalfields in the state of Chhattisgarh, with reserves approximately 19106 million tons. Scientific data with respect to petrographic, geochemical, peat evolution and coal utilization aspects have not been dealt systematically. The earlier studies focused on coal resources of Mand-Raigarh coalfield (Medlicot and Blanford 1879) and Raja Rao (1983). This 


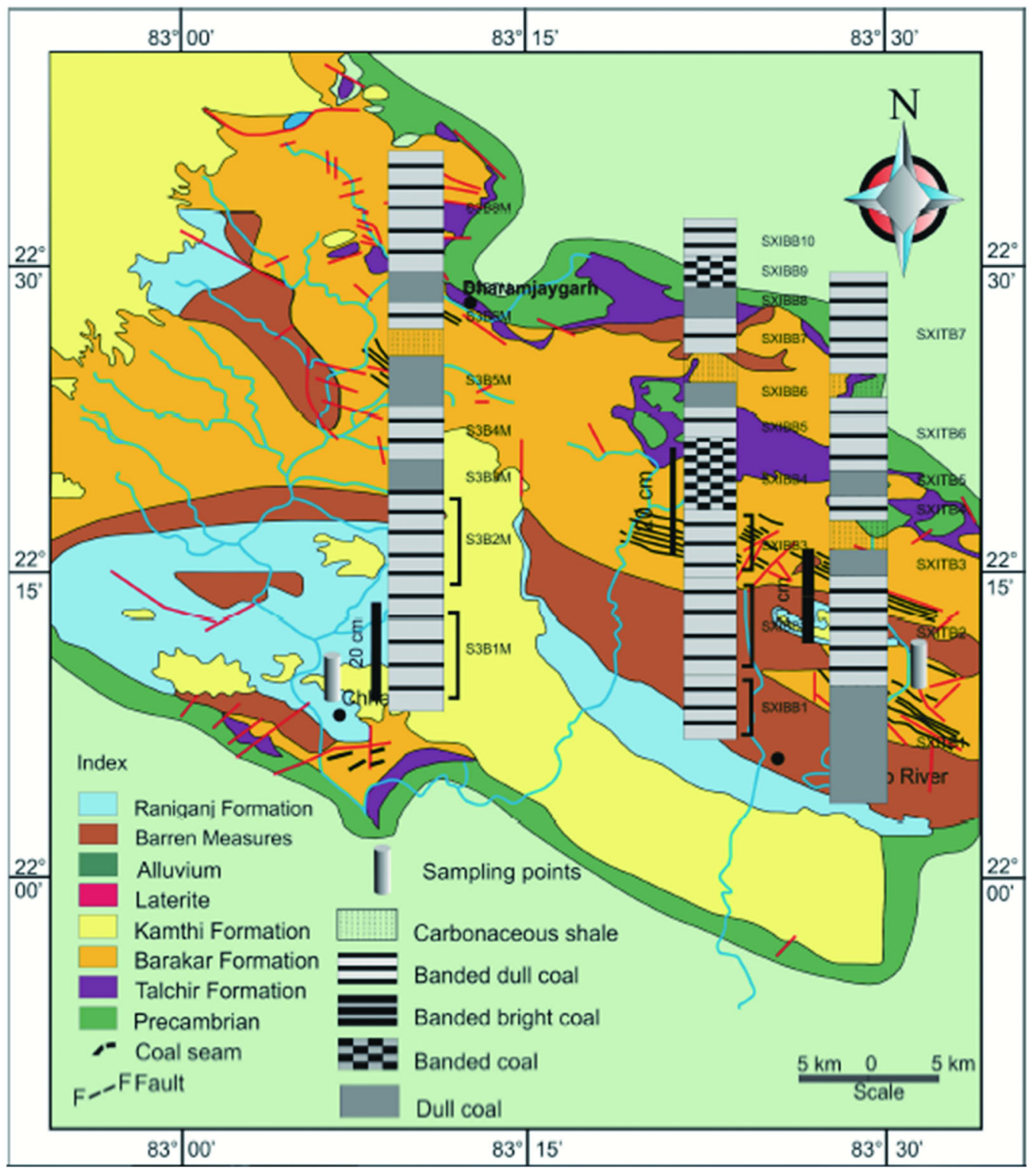

Fig. 1 Geological map of Mand-Raigarh Coalfield

coalfield has attracted scientific investigation mostly on palynological aspects (Chakraborti and Chakraborty 2001; Chakraborti and Ram-Awatar 2006; Murthy et al. 2014; Jana et al. 2002). Ram-Awatar (2007) made palyno-stratigraphy as well as depositional environment. This research was undertaken to make an attempt to address these gaps of information pertaining to the coals of Mand-Raigarh coalfield. The core objective of investigation has been to work out petrographic evaluation throwing light on the maceral and microlithotype composition, source rock potential for hydrocarbon and an effort shall be made for palaeoenvironment reconstruction.

\section{Geological setting}

Mand-Raigarh coal field lies in northwest-southeasterly elongated Mahanadi Gondwana Basin located in the eastcentral part of India, bounded by latitudes $21^{\circ} 45^{\prime} 00^{\prime \prime}$ and $22^{\circ} 40^{\prime} 00^{\prime \prime} \mathrm{N}$; by longitudes $82^{\circ} 55^{\prime} 00^{\prime \prime}$ and $83^{\circ} 35^{\prime} 00^{\prime \prime} \mathrm{E}$. This coal bearing Gondwana Basin covers an area of about $2000 \mathrm{~km}^{2}$ (Fig. 1). The political boundary between the states of Chhattisgarh and Odisha demarcates the eastern boundary of this coalfield but the continuity of coal bearing sedimentary sequence has been established to the east and southeast in Ib-River coalfield (Singh et al. 2007; Goswami 2008; Singh et al. 2010), western boundary of the Mand- 
Raigarh coalfield is an intervening watershed of hill forming Kamthi Formation, separating Mand-Raigarh coalfield in the east and Korba coalfield in the west. To the northwest, Mand-Raigarh coalfield is separated from northerly located Hasdo-Arand coalfield by an east-west trending fault system of Tan Shear Zone which is a part of Central Indian Suture (CIS) zone.

Exploration and mapping was carried out by the Geological Survey of India with detailed correlation of the borehole data, a total of twelve seams have been established in Mand-Raigarh coalfields and all the coal seams belong to the Barakar Formation (Table 1). The present study is based on three exposed and working coal seams viz. Seam-III, Seam-XI top and Seam-XI bottom. The initial underground projects for coal mining were opened at Chhal and Dharam underground mines, where Seam-III is being exploited. Seam-III attains thickness of over 3-5 m. Seam-XI top and Seam-XI bottom are exploited at Baroud opencast mine. The seams under active exploitation have partings in general and their occurrence is not concurrent in all parts of the coalfield. The Mand-Raigarh Coalfield is an asymmetrical basin with an approximately NW-SE axis It displays a typical half—graben configuration. The beds dip at low angle of $5^{\circ}-7^{\circ}$ towards south-west. This basin comprises normal Gravity faults. Two sets of faults trending WNW-ESE to NW-SE and N-S occur. The amount of throw varies from 10 to $150 \mathrm{~m}$.

\section{Material and analytical methods}

Total 46 block pillar coal samples representing vertical profile of the coal seams (seam-III, seam-XI bottom and seam-XI top) were collected from the working faces of the mines in Mand-Raigarh coalfield. The relative position of the samples with reconstructed megascopic seam profile is represented in Figs. 1-4. The samples were combined and
30 composite samples were made. For petrographic analyses, coal samples were crushed to \pm 18 mesh size $(>1 \mathrm{~mm})$ and polished resin bound particulate pellets were prepared. Maceral and microlithotype investigation was done using Leitz microscopes under monochromatic and UV reflected light with oil immersion objectives. The line to line and point to point spacing were kept at $0.4 \mathrm{~mm}$ and for each sample 1000 counts were taken. The terminologies for vitrinite macerals given by Stach et al. $(1982,1985)$; Taylor et al. (1998); ICCP (1998), and that of inertinite given by ICCP (2001) have been followed.

The vitrinite reflectance was measured with the help of Leitz Orthoplan-pol microscope aided with Leitz M.P.V. photometry system under monochromatic light of $546 \mathrm{~nm}$. The proximate analysis was carried out as per Bureau of Indian Standards (BIS) (2003). The rank of coal was determined by measuring random reflectance on collotelinite grains. The elemental analysis $(\mathrm{C}, \mathrm{H}, \mathrm{N}, \mathrm{O}$, and $\mathrm{S}$ ) was performed at CDRI (Central Drug Research Institute), Lucknow on Vario EL-III Elemental Analyzer. The pyrolysis experiment was carried out on RockEval-II as proposed by Espitalie et al. (1977), Tissot and Welte (1984), Peters (1986), Tyson (1995) and Hunt (1996) at the Keshav Dev Malviya Institute of Petroleum Exploration (KDMIPE), Dehradun, India.

\section{Results and discussion}

\subsection{Macroscopic description of the coal seams}

The macroscopic description was done following the methodology given by Diessel classification (1965) for the humic coals. The coal seams show systematic variation in the nature of banding (Figs. 2-4). Seam-III is dominated by banded dull coal $(75 \%)$ with intermittent bands of dull coal $(\sim 19 \%)$. Seam XI-bottom and seam XI -top contains banded dull coal as dominant bands. The seam XI- bottom

Table 1 Generalized lithostratigraphy of the coalfields (modified after Raja Rao 1983)

\begin{tabular}{|c|c|c|}
\hline Age & Formation & Lithology \\
\hline $\begin{array}{l}\text { Recent cretaceous to } \\
\text { eocene }\end{array}$ & Deccan trap & Alluvium/soil basalt flows and dolerite dykes \\
\hline \multirow[t]{3}{*}{$\begin{array}{l}\text { Permian } \\
\text { Lower to upper }\end{array}$} & Kamthi & $\begin{array}{l}\text { Variegated sandstones with lenses of clay, arenaceous shale, clay beds, carbonaceous } \\
\text { shale and coal seams }\end{array}$ \\
\hline & Barakar formation & Coarse to medium grain sandstones, grits, grey shales and coal seams \\
\hline & Talchir formation & $\begin{array}{l}\text { Diamictites, fine to medium grained Sandstones, olive green shales, rythmites and } \\
\text { turbidites }\end{array}$ \\
\hline Late proterozoic & Chandrapur group & Variegated quartzose sandstone, calcareous, variegated shale \\
\hline Early proterozoic & $\begin{array}{l}\text { Bilaspur, Raigarh, Sundergarh } \\
\text { complex }\end{array}$ & Granite, gneisses, mica schists, quartzites intruded by pegmatites and quartz veins \\
\hline
\end{tabular}




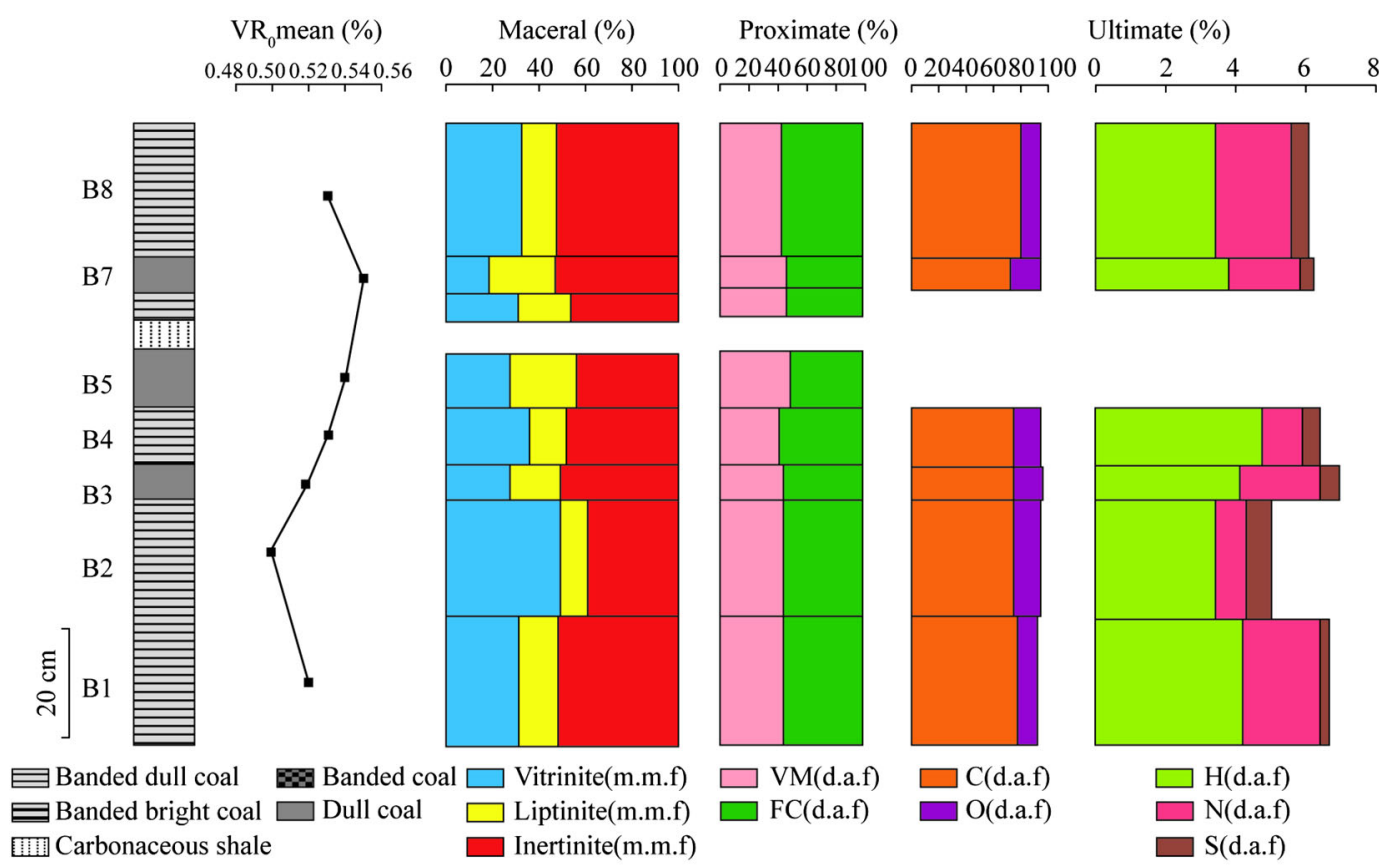

Seam-III

Fig. 2 Macropetrographic seam section with petrographic constituents, reflectance, proximate and ultimate data profile of Seam-III

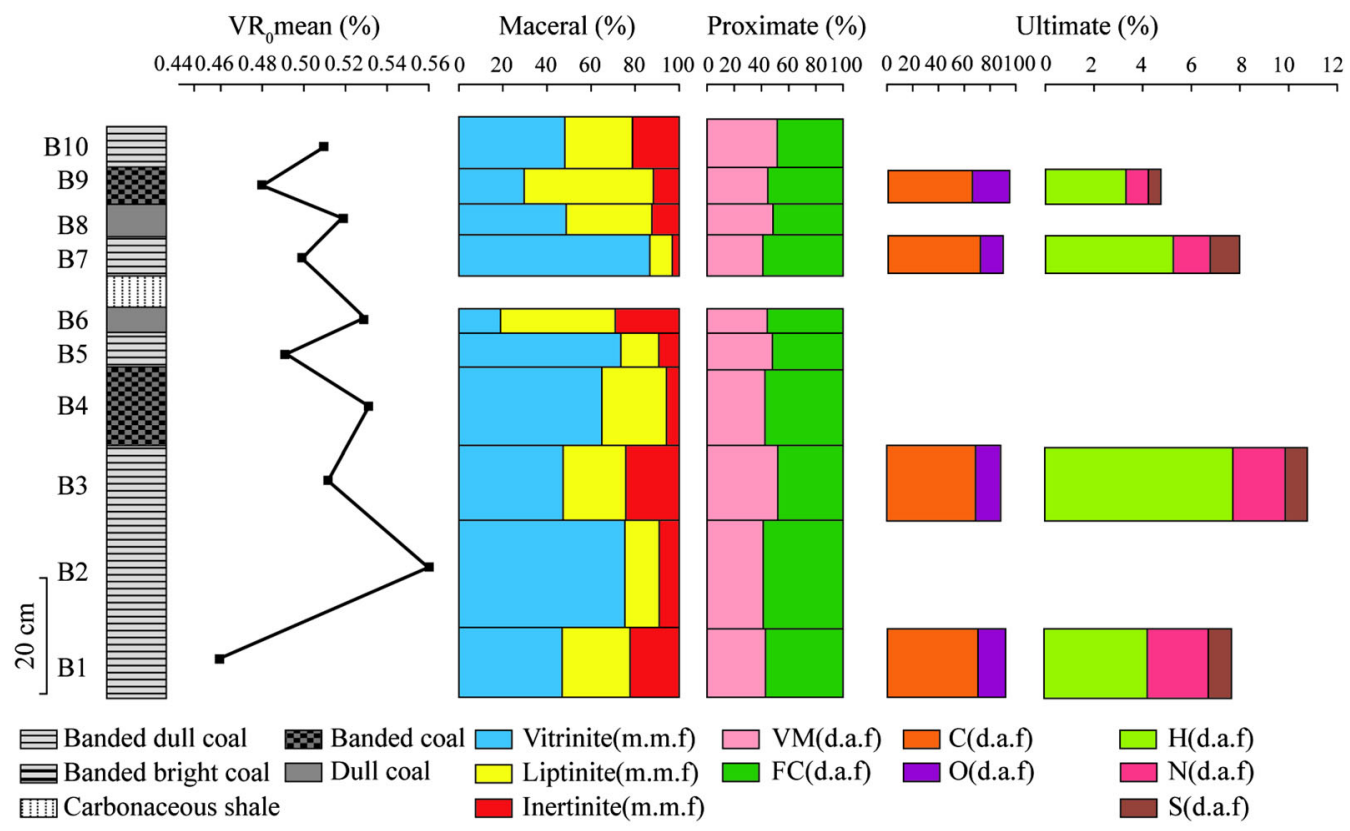

Seam-XI Bottom

Fig. 3 Macropetrographic seam section with petrographic constituents, reflectance, proximate and ultimate data profile-Seam-XI bottom

has more bright components than seam XI-top where banded dull coal constitute $63 \%$ followed by banded coal $(19 \%)$ and dull coal $(10 \%)$ components. Seam XI-top comprises about $58 \%$ banded dull coal and remaining part of the vertical seam profile is composed of dull bands (31\%). 


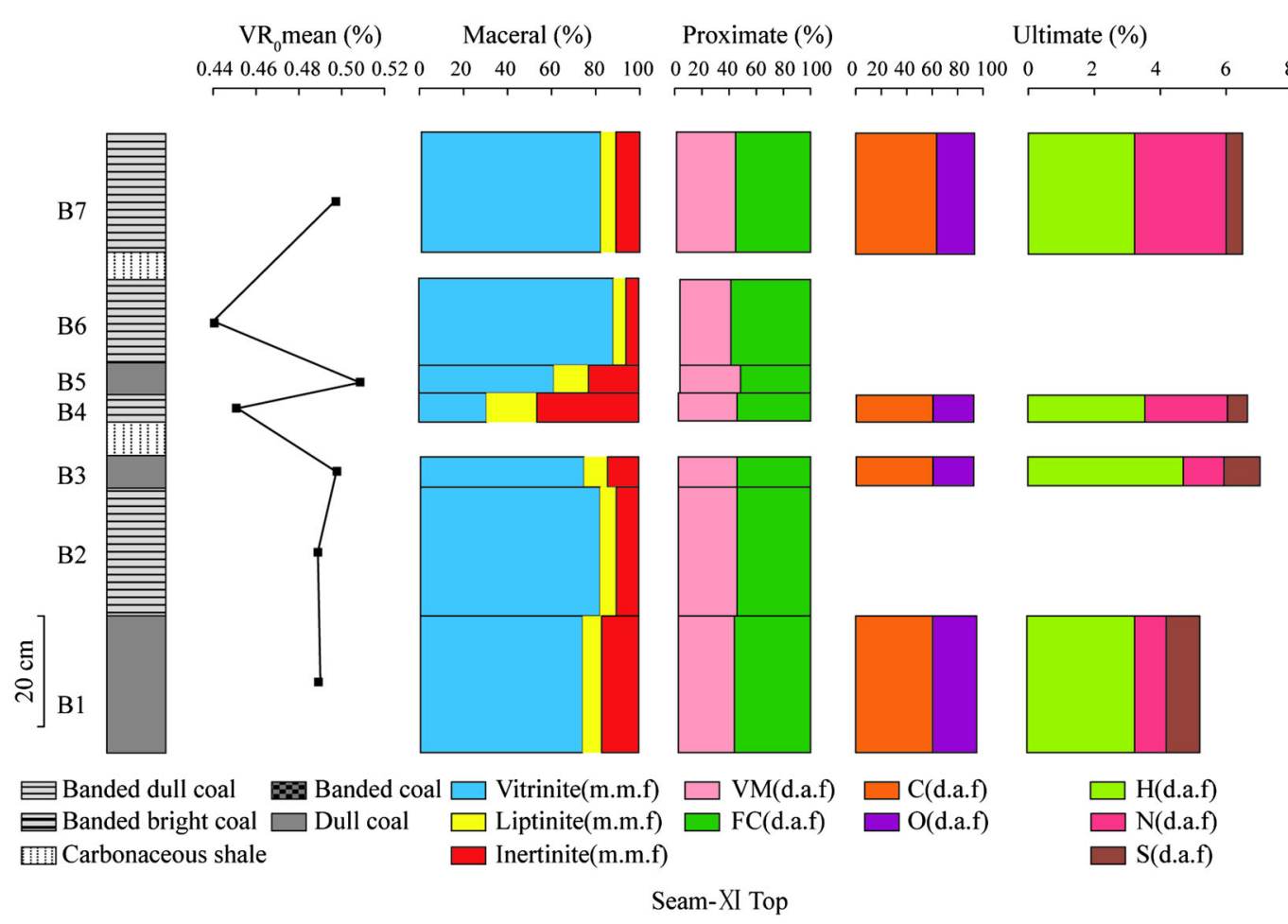

Fig. 4 Macropetrographic seam section with petrographic constituents, reflectance, proximate and ultimate data profile-Seam-XI top

\subsection{Organic petrology}

\subsubsection{Macerals analysis}

The Maceral (Table 2; Fig. 5) analyses of the coals from all the three seams (seam-III, seam-XI bottom and seam-XI top) put together show dominance of vitrinite macerals which is attributed to the type of vegetal input and prevalence of wet environment. Vitrinite range from $15.10 \%$ to $82.50 \%$, mean $44.66 \%$ (17.28\% to $88.29 \%$, mean $51.87 \%$ on m.m.f. basis). The macerals of vitrinite group (Figs. 6 and 7) include telinite, collodetrinite, vitrodetrinite and corpogelinite. The concentration of liptinite varies between $3.00 \%$ and $26.50 \%$, mean $13.61 \%$ (3.52 \% to $29.63 \%$, mean $15.20 \%$ on m.m.f. basis). Among the macerals of liptinite group (Figs. 6 and 7), sporinite is the most common ranging in concentration from $1.70 \%$ to $20.30 \%$, mean $9.52 \%$ (1.92\% to $23.17 \%$, mean $10.63 \%$ on m.m.f. basis). Other macerals of this group include resinite, cutinite and alginite whose occurrence is not as common like other liptinite macerals. The inertinite content of these coals range from $05.00 \%$ to $57.70 \%$, mean $29.80 \%$ (06.30\% to $59.06 \%$, mean $32.93 \%$ on m.m.f. basis). The dominant maceral of this group, fusinite range from $2.60 \%$ to $44.80 \%$, mean $21.16 \%(3.27 \%$ to $45.85 \%$, mean $23.19 \%$ on m.m.f. basis); semifusinite, secretinite, inertodetrinite, macrinite and micrinite are other important macerals of the inertinite group (Figs. 6, 7).

\section{Mineral matter}

The mineral matter in coal poses major problem during coal utilization (Singh et al. 2015). Mineral matter is ubiquitous environmental contaminant in Indian Gondwana coals. The qualitative and quantitative study of mineral matter was done in white incident light. The dominant mineral matters occur as detrital clays, pyrites as disseminated, framboidal and euhedral forms are also present. The detrital clay in the coal is suggestive of high water cover in the basin which is also indicated by high concentration of vitrinite maceral. The mineral matter range from $2.30 \%$ to $51.30 \%$, mean $11.94 \%$. Out of which clay minerals range from $2.10 \%$ to $19.20 \%$, mean $8.49 \%$; the pyrite minerals from nil to $7.40 \%$ mean $1.50 \%$; carbonate minerals from nil to $46.50 \%$, mean $1.94 \%$ and silicates were observed in very small amount. In seam-III, concentration of mineral matter range from $2.90 \%$ to $12.40 \%$, mean $5.05 \%$. Pyrite and siderite are the common minerals, euhedral crystals (Fig. 8c) and framboidal pyrites are recorded in sample S3B1 M (Fig. 8d). It is interesting to note that in sample S3B8 M, epigenetic pyrite (Fig. 8e) has been observed; replacement has systematically advanced from the periphery of the cell walls towards the core of the cell lumens. The epigenetic pyrites are observed in the fractures and as cavity fillings which is suggestive of anoxic environment during the peat development. In seam-XI bottom, concentration of mineral matter range from $2.30 \%$ to $22.40 \%$, mean $9.74 \%$ and in 
Table 2 Maceral composition of the coal seams (in volume percentage)

\begin{tabular}{|c|c|c|c|c|c|c|c|c|c|c|c|}
\hline \multirow[t]{2}{*}{ Macerals } & \multicolumn{11}{|c|}{ SEAM-III } \\
\hline & B1 & & & B3 & B4 & B5 & B6 & & B7 & B8 & Mean \\
\hline Tellinite & 0.0 & & & 0.0 & 0.0 & 0.3 & 0.5 & & 0.0 & 0.4 & 0.1 \\
\hline Collotelinite & 28.3 & & & 26.6 & 35.2 & 23.0 & 29.10 & & 18.0 & 30.1 & 29.6 \\
\hline Vitrodetrinite & 1.2 & & & 0.3 & 0.0 & 0.4 & 0.80 & & 0.2 & 1.5 & 0.6 \\
\hline Pseudovitrinite & 0.0 & & & 0.0 & 0.0 & 0.0 & 0.00 & & 0.0 & 0.1 & 0.01 \\
\hline Collodetrinite & 0.4 & & & 0.1 & 0.0 & 0.6 & 0.10 & & 0.0 & 0.4 & 0.2 \\
\hline Corpogelinite & 0.0 & & & 0.0 & 0.0 & 0.0 & 0.00 & & 0.0 & 0.0 & 0.01 \\
\hline Total vitrinite & 29.9 & & & 27.0 & 35.2 & 24.3 & 30.50 & & 18.2 & 32.5 & 30.7 \\
\hline Fusinite & 39.4 & & & 34.9 & 36.9 & 30.7 & 31.20 & & 41.1 & 39.0 & 35.2 \\
\hline Semi- fusinite & 5.0 & & & 6.9 & 4.5 & 2.2 & 9.50 & & 3.8 & 7.9 & 5.4 \\
\hline Secretinite & 0.1 & & & 0.0 & 0.0 & 0.0 & 0.00 & & 0.0 & 0.1 & 0.03 \\
\hline Macrinite & 0.9 & & & 1.2 & 0.4 & 1.2 & 0.00 & & 0.6 & 1.0 & 0.7 \\
\hline Micrinite & 0.2 & & & 0.4 & 0.3 & 0.1 & 0.00 & & 0.2 & 0.2 & 0.1 \\
\hline Funginite & 0.1 & & & 0.0 & 0.0 & 0.0 & 0.00 & & 0.0 & 0.0 & 0.01 \\
\hline Inertodetrinite & 4.0 & & & 5.5 & 3.4 & 3.5 & 4.40 & & 3.2 & 2.8 & 3.8 \\
\hline Total inertinite & 49.7 & & & 48.9 & 45.5 & 37.7 & 45.10 & & 48.9 & 51.0 & 45.5 \\
\hline Alginite & 0.2 & & & 0.0 & 0.1 & 0.1 & 0.00 & & 0.0 & 0.0 & 0.0 \\
\hline Cutinite & 13.1 & & & 4.3 & 2.3 & 5.1 & 6.30 & & 11.6 & 3.9 & 6.0 \\
\hline Sporinite & 2.3 & & & 16.4 & 12.8 & 20.3 & 15.10 & & 14.8 & 9.0 & 12.4 \\
\hline Liptodetrinite & 0.0 & & & 0.0 & 0.0 & 0.0 & 0.00 & & 0.1 & 0.0 & .01 \\
\hline Resinite & 0.1 & & & 0.0 & 0.1 & 0.0 & 0.00 & & 0.0 & 0.3 & .06 \\
\hline Megaspore & 0.0 & & & 0.0 & 0.0 & 0.0 & 0.00 & & 0.0 & 0.0 & 0.0 \\
\hline Megacutinite & 0.0 & & & 0.0 & 0.0 & 0.0 & 0.00 & & 0.0 & 0.0 & 0.0 \\
\hline Degraded pollens & 0.3 & & & 0.0 & 0.0 & 0.1 & 0.10 & & 0.0 & 0.0 & .06 \\
\hline Bituminite & 0.0 & & & 0.0 & 0.0 & 0.0 & 0.00 & & 0.0 & 0.0 & 0.0 \\
\hline Exudatinite & 0.0 & & & 0.0 & 0.0 & 0.0 & 0.00 & & 0.0 & 0.00 & 0.0 \\
\hline Total liptinite & 16.0 & & & 20.7 & 15.3 & 25.6 & 21.50 & & 26.5 & 13.2 & 18.6 \\
\hline Argillaceous & 4.1 & & & 3.3 & 3.9 & 12.1 & 2.90 & & 6.2 & 2.1 & 4.7 \\
\hline Sulphides & 0.3 & & & 0.1 & 0.1 & 0.3 & 0.00 & & 0.2 & 1.2 & 0.3 \\
\hline Carbonates & 0.0 & & & 0.0 & 0.0 & 0.0 & 0.00 & & 0.0 & 0.0 & 0.0 \\
\hline Silicates & 0.0 & & & 0.0 & 0.0 & 0.0 & 0.00 & & 0.0 & 0.0 & 0.0 \\
\hline Total mineral matter & 4.4 & & & 3.4 & 4.0 & 12.4 & 2.90 & & 6.4 & 3.3 & 5.0 \\
\hline \multirow[t]{2}{*}{ Macerals } & \multicolumn{11}{|c|}{ SEAM-XI bottom } \\
\hline & B1 & B2 & B3 & B4 & B5 & B6 & B7 & B8 & B9 & B10 & Mean \\
\hline Tellinite & 0.0 & 0.1 & 0.3 & 0.5 & 0.7 & 0.3 & 0.0 & 0.0 & 0.4 & 0.1 & 0.2 \\
\hline Collotelinite & 40.0 & 71.6 & 42.1 & 58.0 & 61.1 & 14.6 & 81.3 & 36.7 & 28.5 & 42.2 & 47.6 \\
\hline Vitrodetrinite & 0.1 & 0.6 & 0.4 & 0.3 & 0.6 & 0.2 & 0.2 & 0.9 & 0.7 & 0.3 & 0.4 \\
\hline Pseudovitrinite & 0.0 & 0.0 & 0.0 & 0.0 & 0.0 & 0.0 & 0.0 & 0.0 & 0.0 & 0.0 & 0.0 \\
\hline Collodetrinite & 0.4 & 0.3 & 0.8 & 0.9 & 0.7 & 0.0 & 1.0 & 0.6 & 0.6 & 1.0 & 0.6 \\
\hline Corpogelinite & 0.0 & 0.0 & 0.0 & 0.0 & 0.8 & 0.0 & 0.0 & 0.0 & 0.0 & 0.0 & 0.0 \\
\hline Total vitrinite & 40.5 & 72.6 & 43.6 & 59.7 & 63.9 & 15.1 & 82.5 & 38.2 & 30.2 & 43.6 & 48.9 \\
\hline Fusinite & 19.7 & 7.8 & 18.5 & 16.9 & 7.2 & 38.2 & 3.6 & 18.2 & 44.8 & 18.5 & 19.3 \\
\hline Semi- fusinite & 3.2 & 3.6 & 1.7 & 5.6 & 3.7 & 0.6 & 2.0 & 3.5 & 5.1 & 1.7 & 3.0 \\
\hline Secretinite & 0.0 & 0.0 & 0.1 & 0.0 & 0.0 & 0.4 & 0.0 & 0.1 & 0.0 & 0.1 & 0.0 \\
\hline Macrinite & 0.3 & 0.4 & 1.8 & 0.7 & 0.5 & 3.0 & 0.2 & 0.7 & 0.1 & 1.8 & 0.9 \\
\hline Micrinite & 0.1 & 0.1 & 0.5 & 0.2 & 0.2 & 1.5 & 0.0 & 0.2 & 0.0 & 0.5 & 0.3 \\
\hline Funginite & 0.0 & 0.0 & 0.0 & 0.0 & 0.0 & 0.0 & 0.0 & 0.0 & 0.0 & 0.0 & 0.0 \\
\hline
\end{tabular}


Table 2 continued

\begin{tabular}{|c|c|c|c|c|c|c|c|c|c|c|c|}
\hline \multirow[t]{2}{*}{ Macerals } & \multicolumn{11}{|c|}{ SEAM-XI bottom } \\
\hline & B1 & B2 & B3 & B4 & B5 & B6 & B7 & B8 & B9 & B10 & Mean \\
\hline Inertodetrinite & 3.3 & 3.5 & 4.9 & 3.9 & 2.6 & 2.7 & 2.2 & 7.2 & 7.7 & 4.9 & 4.2 \\
\hline Total inertinite & 26.6 & 15.4 & 27.5 & 27.3 & 14.2 & 46.4 & 8.0 & 29.9 & 57.7 & 27.5 & 28.0 \\
\hline Alginite & 0.0 & 0.0 & 0.0 & 0.0 & 0.0 & 0.0 & 0.0 & 0.0 & 0.0 & 0.0 & 0.0 \\
\hline Cutinite & 6.9 & 1.3 & 2.9 & 0.8 & 1.0 & 11.0 & 1.4 & 2.4 & 5.2 & 2.7 & 3.5 \\
\hline Sporinite & 12.5 & 6.4 & 17.9 & 6.2 & 6.9 & 14.3 & 1.8 & 7.0 & 4.5 & 17.8 & 9.5 \\
\hline Liptodetrinite & 0.0 & 0.0 & 0.0 & 0.0 & 0.0 & 0.0 & 0.0 & 0.0 & 0.0 & 0.0 & 0.0 \\
\hline Resinite & 0.0 & 0.0 & 0.0 & 0.0 & 0.0 & 0.0 & 0.0 & 0.0 & 0.0 & 0.0 & 0.0 \\
\hline Megaspore & 0.0 & 0.0 & 0.0 & 0.0 & 0.0 & 0.0 & 0.1 & 0.0 & 0.0 & 0.0 & 0.01 \\
\hline Megacutinite & 0.0 & 0.0 & 0.0 & 0.0 & 0.0 & 0.0 & 0.0 & 0.1 & 0.0 & 0.0 & 0.01 \\
\hline Degraded pollens & 0.1 & 0.0 & 0.0 & 0.0 & 0.0 & 0.5 & 0.0 & 0.0 & 0.1 & 0.2 & 0.09 \\
\hline Bituminite & 0.0 & 0.0 & 0.0 & 0.0 & 0.0 & 0.0 & 0.0 & 0.0 & 0.0 & 0.1 & 0.01 \\
\hline Exudatinite & 0.0 & 0.0 & 0.0 & 0.0 & 0.0 & 0.1 & 0.0 & 0.0 & 0.0 & 0.0 & 0.01 \\
\hline Total liptinite & 19.5 & 7.7 & 20.8 & 7.0 & 7.9 & 25.9 & 3.3 & 9.5 & 9.8 & 20.8 & 13.2 \\
\hline Argillaceous & 12.4 & 4.0 & 7.4 & 5.9 & 13.5 & 12.3 & 5.0 & 21.3 & 2.2 & 7.4 & 9.1 \\
\hline Sulphides & 1.0 & 0.2 & 0.5 & 0.1 & 0.5 & 0.3 & 1.2 & 1.1 & 0.1 & 0.5 & 0.5 \\
\hline Carbonates & 0.0 & 0.0 & 0.2 & 0.0 & 0.0 & 0.0 & 0.0 & 0.0 & 0.0 & 0.2 & 0.04 \\
\hline Silicates & 0.0 & 0.1 & 0.0 & 0.0 & 0.0 & 0.0 & 0.0 & 0.0 & 0.0 & 0.0 & 0.01 \\
\hline Total mineral matter & 13.4 & 4.3 & 8.1 & 6.0 & 14.0 & 12.6 & 6.2 & 22.4 & 2.3 & 8.1 & 9.7 \\
\hline \multirow[t]{2}{*}{ Macerals } & \multicolumn{11}{|c|}{ SEAM-XI top } \\
\hline & B1 & & B2 & B3 & B4 & & B5 & B6 & & B7 & Mean \\
\hline Tellinite & 0.3 & & 0.6 & 1.1 & 0.0 & & 0.1 & 0.3 & & 0.1 & 0.3 \\
\hline Collotelinite & 35.0 & & 62.0 & 57.9 & 23.6 & & 54.0 & 69.5 & & 64.4 & 47.3 \\
\hline Vitrodetrinite & 0.8 & & 1.8 & 0.8 & 0.4 & & 0.1 & 0.0 & & 0.0 & 0.4 \\
\hline Pseudovitrinite & 0.1 & & 0.0 & 0.0 & 0.0 & & 0.0 & 0.0 & & 0.8 & 0.1 \\
\hline Collodetrinite & 0.7 & & 1.5 & 0.0 & 0.8 & & 0.5 & 0.0 & & 0.1 & 0.4 \\
\hline Corpogelinite & 0.1 & & 0.7 & 1.0 & 0.0 & & 0.1 & 0.3 & & 1.2 & 0.4 \\
\hline Total vitrinite & 37.0 & & 66.6 & 60.8 & 24.8 & & 54.8 & 70.1 & & 66.6 & 49.1 \\
\hline Fusinite & 4.0 & & 4.1 & 5.6 & 21.2 & & 11.7 & 2.6 & & 4.1 & 7.0 \\
\hline Semi- fusinite & 1.4 & & 2.0 & 2.5 & 2.1 & & 3.3 & 1.6 & & 2.0 & 1.9 \\
\hline Secretinite & 0.0 & & 0.1 & 0.0 & 0.0 & & 0.0 & 0.0 & & 0.1 & 0.0 \\
\hline Macrinite & 0.1 & & 0.0 & 0.1 & 0.6 & & 1.2 & 0.2 & & 0.0 & 0.3 \\
\hline Micrinite & 0.1 & & 0.0 & 0.0 & 0.1 & & 0.7 & 0.0 & & 0.0 & 0.1 \\
\hline Funginite & 0.0 & & 0.0 & 0.0 & 0.0 & & 0.0 & 0.0 & & 0.0 & 0.0 \\
\hline Inertodetrinite & 2.7 & & 1.4 & 3.2 & 14.5 & & 4.7 & 0.6 & & 1.4 & 3.6 \\
\hline Total inertinite & 8.3 & & 7.6 & 11.4 & 38.5 & & 21.6 & 5.0 & & 7.6 & 13.1 \\
\hline Alginite & 0.0 & & 0.0 & 0.0 & 0.0 & & 0.0 & 0.0 & & 0.0 & 0.0 \\
\hline Cutinite & 1.3 & & 0.1 & 0.5 & 10.0 & & 1.2 & 1.3 & & 0.1 & 1.8 \\
\hline Sporinite & 1.7 & & 6.0 & 8.0 & 6.9 & & 11.9 & 2.9 & & 6.0 & 5.9 \\
\hline Liptodetrinite & 0.0 & & 0.0 & 0.0 & 0.0 & & 0.1 & 0.0 & & 0.0 & .01 \\
\hline Resinite & 0.0 & & 0.0 & 0.1 & 0.0 & & 0.0 & 0.0 & & 0.0 & .01 \\
\hline Megaspore & 0.0 & & 0.0 & 0.0 & 0.0 & & 0.0 & 0.0 & & 0.0 & 0.0 \\
\hline Megacutinite & 0.0 & & 0.0 & 0.0 & 0.0 & & 0.1 & 0.0 & & 0.0 & .01 \\
\hline Degraded pollens & 0.0 & & 0.0 & 0.0 & 0.3 & & 0.1 & 0.1 & & 0.0 & .07 \\
\hline Bituminite & 0.0 & & 0.0 & 0.0 & 0.0 & & 0.0 & 0.0 & & 0.0 & 0.0 \\
\hline Exudatinite & 0.0 & & 0.0 & 0.0 & 0.0 & & 0.0 & 0.0 & & 0.0 & 0.0 \\
\hline Total liptinite & 3.0 & & 6.1 & 8.6 & 17.2 & & 13.4 & 4.3 & & 6.1 & 7.9 \\
\hline
\end{tabular}


Table 2 continued

\begin{tabular}{|c|c|c|c|c|c|c|c|c|}
\hline \multirow[t]{2}{*}{ Macerals } & \multicolumn{8}{|c|}{ SEAM-XI top } \\
\hline & B1 & B2 & B3 & B4 & B5 & B6 & B7 & Mean \\
\hline Argillaceous & 2.8 & 12.2 & 12.2 & 19.2 & 9.4 & 14.9 & 12.2 & 11.4 \\
\hline Sulphides & 2.4 & 7.4 & 5.6 & 0.2 & 0.8 & 5.7 & 7.4 & 3.8 \\
\hline Carbonates & 46.5 & 0.1 & 1.4 & 0.1 & 0.0 & 0.0 & 0.1 & 0.2 \\
\hline Silicates & 0.0 & 0.0 & 0.0 & 0.0 & 0.0 & 0.0 & 0.0 & 0.0 \\
\hline Total mineral matter & 51.7 & 19.7 & 19.2 & 19.5 & 10.2 & 20.6 & 19.7 & 15.5 \\
\hline
\end{tabular}

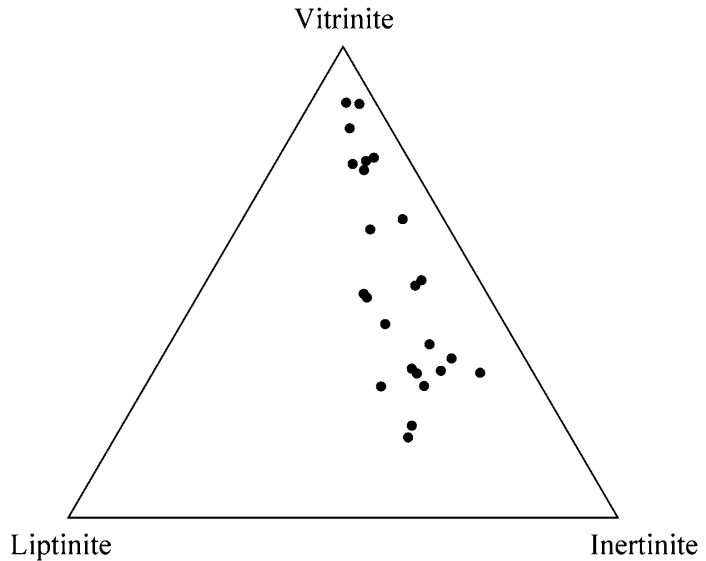

Fig. 5 Ternary diagram showing maceral distribution

seam-XI top, concentration of mineral matter range from $10.20 \%$ to $51.70 \%$, mean $15.56 \%$. Apart from argillaceous mineral matter, high amount of siderite (Fig. 8f) was observed in sample (SXITB1).

\section{Microlithotype analysis}

Microlithotypes are basically association of macerals among themselves and the carbominerites are the association of macerals with mineral matter. The microlitotypes provide information about the evolution of the peat and its precursors. All the microlithotype groups, viz. monomaceral (vitrite, liptite, inertite), bimaceral (clarite, vitrinertite, durite) and trimacerite (duroclarite and clarodurite) as well as carbominerite have been recorded in the investigated coals. Vitrite remains to be the dominant microlithotype in the coals (Table 3) which is also indicated by high vitrinite content.

In the studied coals, vitrite range from $13.23 \%$ to $81.29 \%$, mean $40.68 \%$ (13.57\% to $84.90 \%$, mean $45.42 \%$ on m.m.f. basis); inertite from $3.40 \%$ to $40.99 \%$, mean $21.14 \%$ (3.55 \% to $44.14 \%$, mean $22.81 \%$ on m.m.f. basis); liptite from nil to $2.18 \%$, mean $0.44 \%$ (nil to $2.43 \%$, mean $0.48 \%$ on m.m.f. basis);Clarite range from $1.95 \%$ to
$21.44 \%$, mean $11.95 \%$ (2.71\% to $25.80 \%$, mean $13.20 \%$, on m.m.f. basis); Vitrinertite range from $1.27 \%$ to $13.47 \%$ mean $8.28 \%$ (1.57\% to $14.18 \%$ mean $9.03 \%$, on m.m.f. basis); Durite range from nil to $24.63 \%$, mean $8.27 \%$ (nil to $32.04 \%$, mean $8.91 \%$, on m.m.f. basis); Duroclarite range from nil to $0.58 \%$, mean $0.12 \%$ (nil to $0.60 \%$, mean $0.13 \%$, on m.m.f. basis). The trimacerite concentration such as duroclarite, vitrinertoliptite and clarodurite in the coals register less than one percent.

\subsection{Carbominerites}

The maceral-mineral associations in the coals are called carbominerites. The association is related to the genesis of the coal and the macerals in particular. The carbominerite has been characterized as carbargilite, carbankerite and carbopyrite with their quantitative assessment. In the coals of Mand-Raigarh coalfield, carbominerite range from $0.94 \%$ to $28.22 \%$, mean $9.11 \%$. This includes carbargilite from $0.37 \%$ to $26.76 \%$, mean $8.18 \%$; carbopyrite from nil to $1.91 \%$, mean $0.50 \%$ and carbankerite from nil to $5.10 \%$, mean $0.38 \%$ (Table 3). The dominance of carbargillite is suggestive of enrichment of clastic minerals and high water cover in the basin.

\section{Vitrinite reflectance measurements}

Vitrinite reflectance (VR) measurements for the samples were carried out following the procedures of Taylor et al. (1998), using a Leitz microscope with a photometer. An interference filter with a pass band peak of $546 \mathrm{~nm}$ and a $50 \times$ oil immersion objective were used. Vitrinite grains 50 in number were measured using plane polarized light, the maximum reflectances of each sample and the averages of these are reported as the mean maximum VR values. Vitrinite reflectance is used as a tool for the determination of rank and maturation of the coals, the reflectance measurement was carried out on vitrinite (especially collotelinite) grains which were free of any weathering features and contamination (Figs. 3-5). The vitrinite reflectance of the coals of Mand-Raigarh coals shows $R_{\mathrm{o}}$ 


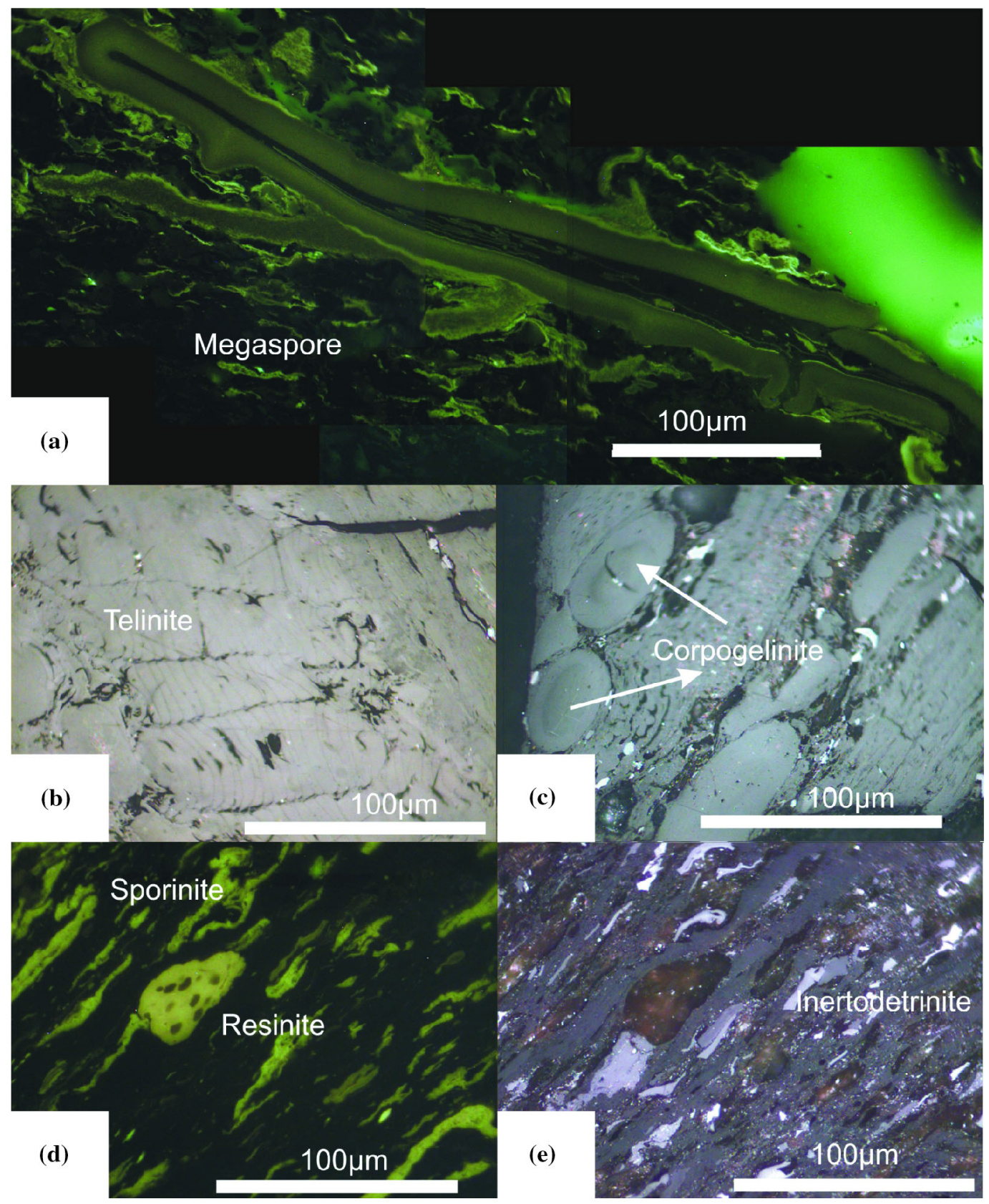

Fig. 6 Photomicrograph of macerals a megaspore under blue light irradiation, $\mathbf{b}$ telinite, $\mathbf{c}$ corpogelinite, $\mathbf{d}$ resinite and Sporinite under blue light irradiation, e same view as $\mathbf{d}$ under reflected white light

min ranging from $0.38 \%$ to $0.49 \%, R_{\mathrm{o}} \max$ from $0.49 \%$ to $0.67 \%$ and $R_{\mathrm{o}}$ mean from $0.44 \%$ to $0.56 \%$ and standard deviation from 0.02 to 0.07 .

\section{Proximate and ultimate analysis}

The seams show varying moisture content between $4.00 \%$ and $10.00 \%$ with a mean of $6.81 \%$. Ash content in coals varies between $10.00 \%$ and $27.00 \%$, with a mean value of
$18.01 \%$. Volatile matter content varies between $22.80 \%$ and $35.40 \%$, with a mean value $29.81 \%$. Fixed carbon range from $38.00 \%$ to $52.50 \%$ with a mean value of $45.36 \%$ (Table 4). Minor increase in the moisture content in seam-XI bottom and seam-XI top is observed as compared to seam-II. All the seam sections display more or less increasing trend in their moisture content from bottom to top in the respective seams. The volatile matter (air dried and d.a.f. basis) show increasing trend from bottom to top of the vertical section (seam-III and seam-XI bottom) but 


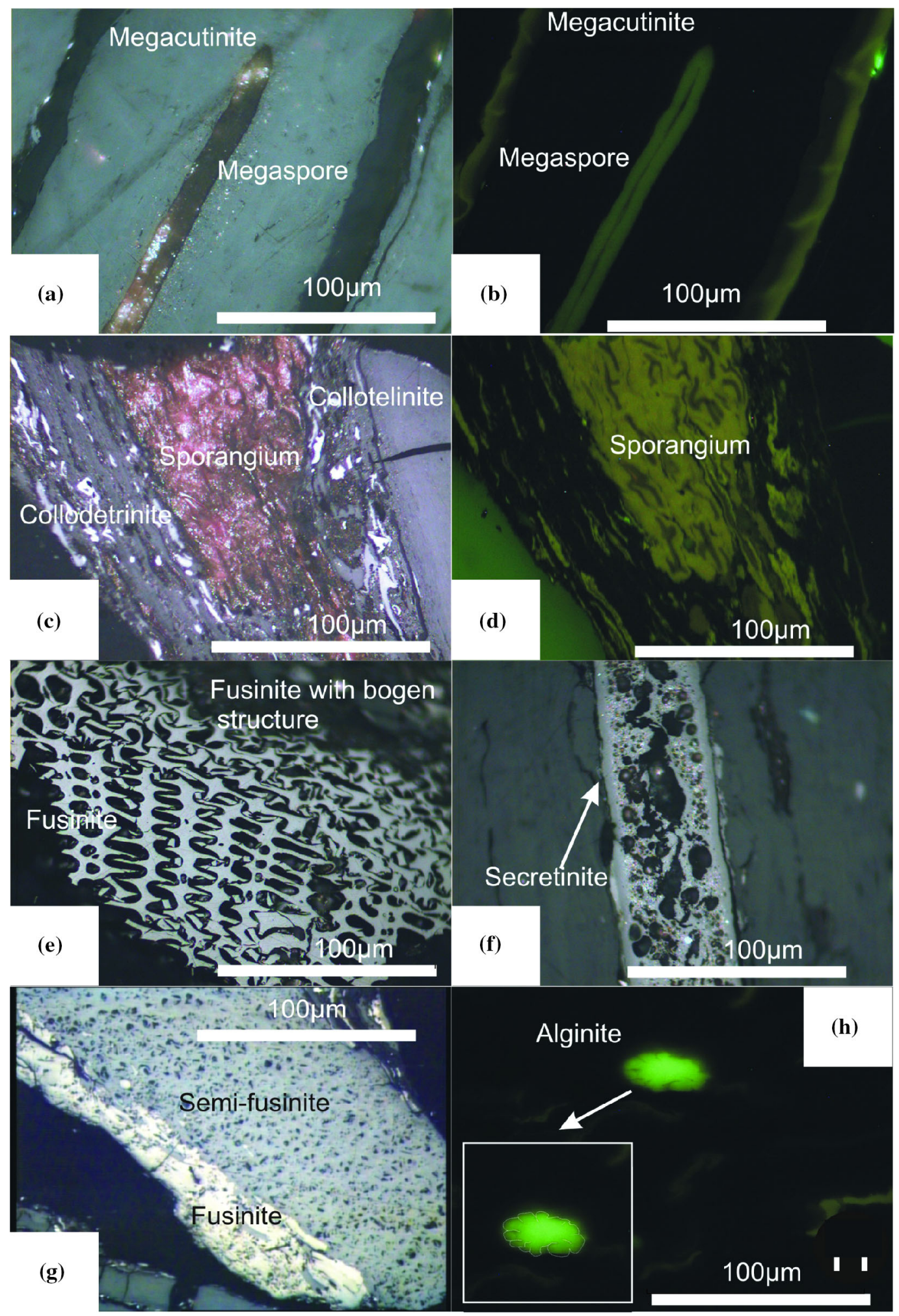

Fig. 7 Photomicrograph of macerals a megaspore and Megacutinite in reflected light, b same view as (a) under blue light irradiation, $\mathbf{c}$ collotelinite and sporangium, $\mathbf{d}$ same view as (c) under blue light irradiation, $\mathbf{e}$ fusinite with bogen structure in upper right corner $\mathbf{f}$ secretinite in ground mass of collodetrinite $\mathbf{g}$ fusinite and semi fusinite (medium gray) $\mathbf{h}$ alginite under blue light irradiation 


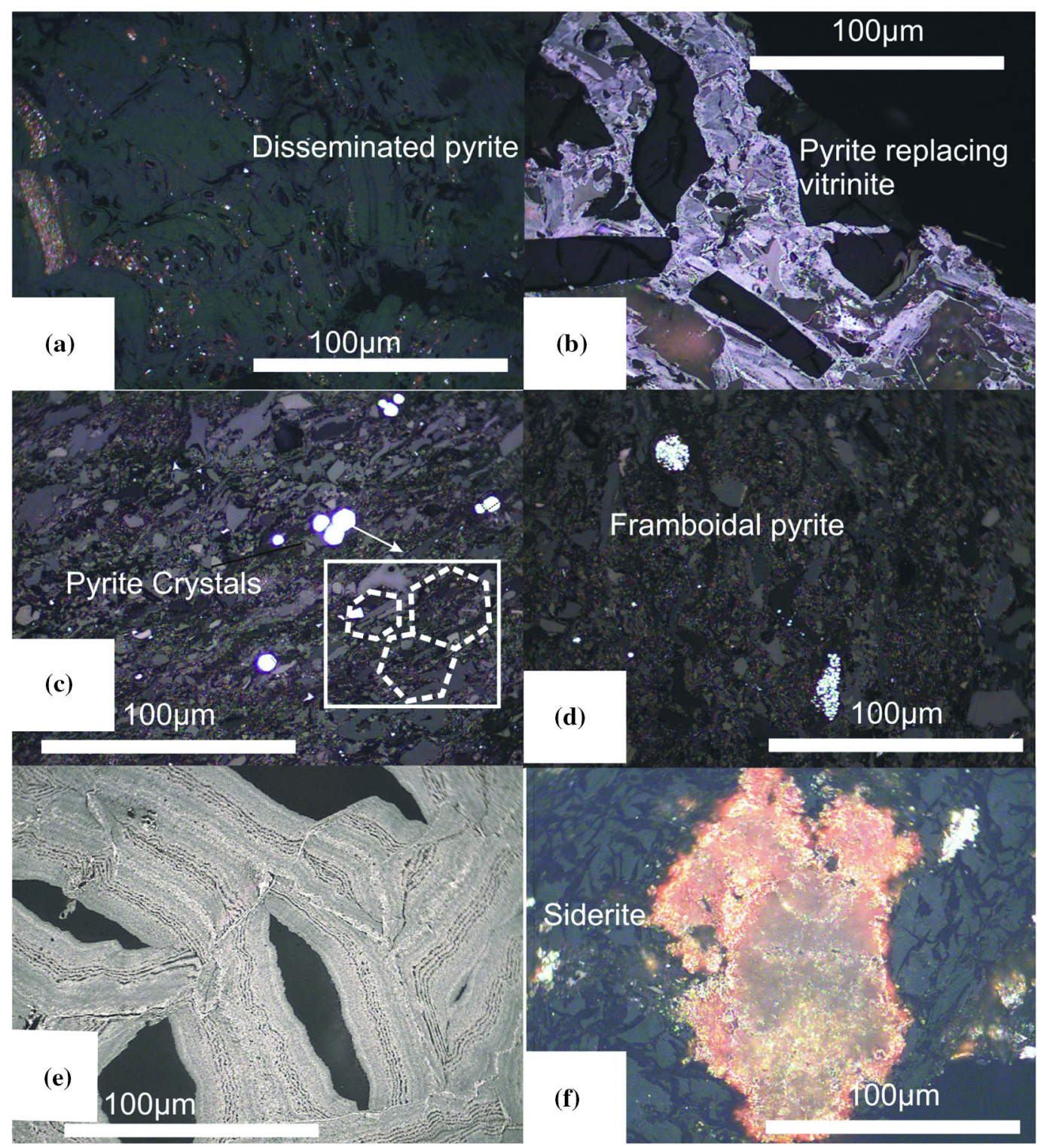

Fig. 8 Photomicrograph of macerals a disseminated pyrite in ground mass of collodetrinite $\mathbf{b}$ pyrite replacing vitrinite $\mathbf{c}$ pyrite showing euhedral crystals $\mathbf{d}$ framboidal pyrite e typical replacement of pyrite $\mathbf{f}$ siderite

has a marginal decrease in the seam XI top. Fixed carbon has lower values in seam XI top.

The elemental compositions of the coal were studied through Ultimate analysis. (Table 4) The carbon content of coals of the studied seams range from $40.46 \%$ to $64.36 \%$, mean $53.87 \%$ (60.39\% to $79.46 \%$, mean $70.29 \%$ on d.a.f. basis); hydrogen range from $2.82 \%$ to $6.74 \%$, mean $3.95 \%$ (3.21\% to $7.74 \%$, mean $4.19 \%$ on d.a.f. basis); Nitrogen range from $0.66 \%$ to $1.94 \%$, mean $1.37 \%$ ( $0.83 \%$ to $2.59 \%$, mean $1.80 \%$ on d.a.f. basis); Oxygen content varies from $16.33 \%$ to $29.31 \%$, mean $23.18 \%$ ( $14.86 \%$ to $29.12 \%$, mean $23.01 \%$ on d.a.f. basis); Sulphur range from $0.22 \%$ to $0.92 \%$, mean $0.53 \%$ ( $0.28 \%$ to $1.23 \%$, mean $0.71 \%$ on d.a.f. basis). All the ultimate constituents show equitable distribution in the coal seams. The carbon content of seam-XI top remains lowest compared to other seams. Hydrogen content of seam-XI bottom registers highest. Oxygen has equitable distribution in the investigated seams which remained more than $20 \%$. Sulphur content $(<1 \%)$ and nitrogen $(<2 \%)$ also have equitable distribution in all the seams registered below one percent. $\mathrm{H} / \mathrm{C}$ ratio and $\mathrm{O} / \mathrm{C}$ ratio plotted in Van krevelen diagram (Fig. 10) corresponds to Type-III Kerogen. None of the samples have $\mathrm{H} / \mathrm{C}$ ratio equal to .9 or more (Hunt 1991; Erik 2011), a prerequisite for petroleum generation and expulsion for sub-bituminous coals, only one sample has registered $\mathrm{H} / \mathrm{C}$ ratio above .9 . The precursors for peat development can be inferred from $\mathrm{C} / \mathrm{N}$ ratio (Tyson 1995; 


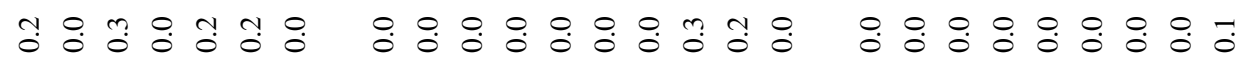

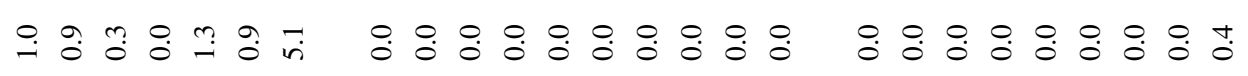

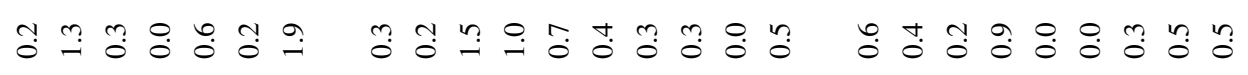

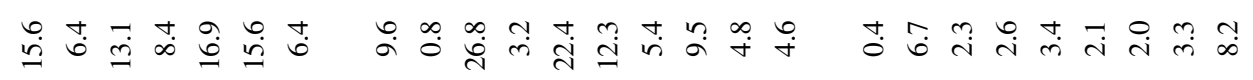

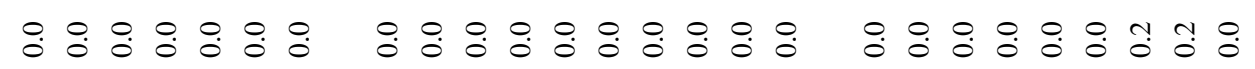

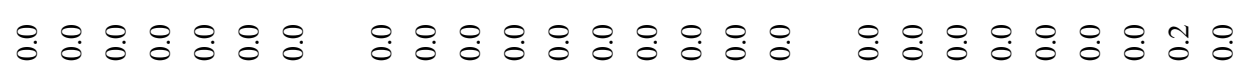

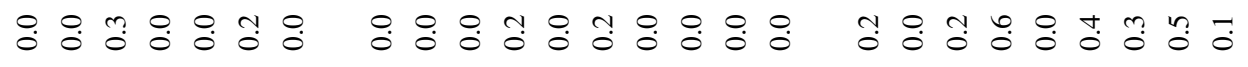

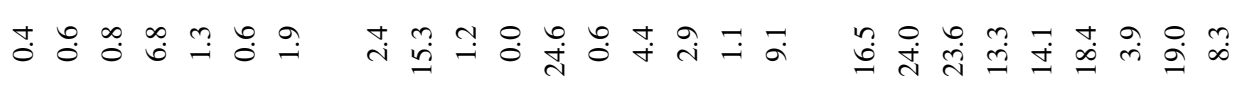

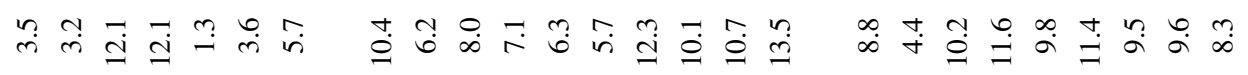

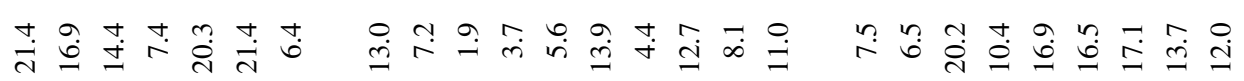

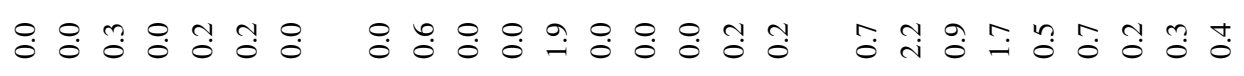

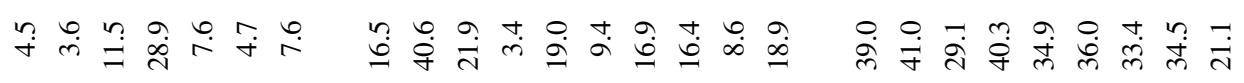

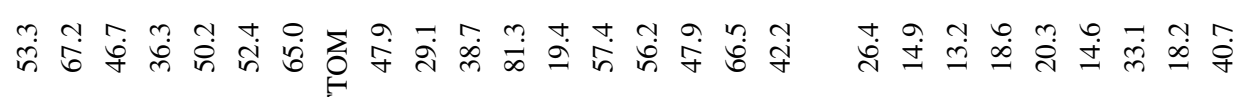
के

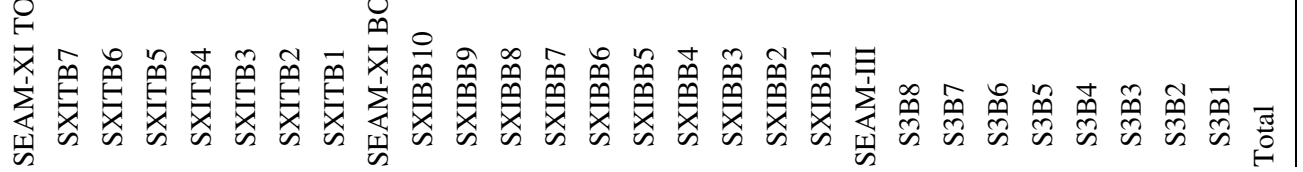


Table 4 Proximate analysis (in wt \%), Ultimate analysis (in wt $\%$ ), and atomic ratios of the coals

\begin{tabular}{|c|c|c|c|c|c|c|c|c|c|c|c|c|c|c|c|}
\hline \multirow[t]{2}{*}{ Sl. no. } & \multirow[t]{2}{*}{ Sample no. } & \multicolumn{4}{|c|}{ Proximate analysis (adb) } & \multicolumn{2}{|c|}{ Proximate (daf) } & \multicolumn{5}{|c|}{ Ultimate analysis (daf) } & \multicolumn{3}{|c|}{ Atomic ratios } \\
\hline & & M & VM & Ash & FC & VM & FC & $\mathrm{C}$ & $\mathrm{H}$ & $\mathrm{N}$ & $\mathrm{S}$ & $\mathrm{O}$ & $\mathrm{H} / \mathrm{C}$ & $\mathrm{O} / \mathrm{C}$ & $\mathrm{C} / \mathrm{N}$ \\
\hline \multicolumn{16}{|c|}{ Seam-XI top } \\
\hline 1 & SXITB7 & 6.00 & 29.00 & 27.00 & 38.00 & 37.31 & 62.69 & 60.39 & 3.21 & 0.99 & 1.04 & 34.38 & 0.69 & 0.53 & 71.17 \\
\hline 2 & SXITB6 & 7.00 & 35.00 & 15.40 & 42.60 & 32.29 & 67.71 & - & - & - & - & - & - & - & - \\
\hline 3 & SXITB5 & 5.00 & 28.00 & 26.00 & 41.00 & 40.91 & 59.09 & - & - & - & - & - & - & - & - \\
\hline 4 & SXITB4 & 6.00 & 27.00 & 26.00 & 41.00 & 39.71 & 60.29 & 60.64 & 4.71 & 1.21 & 1.09 & 32.36 & 0.68 & 0.59 & 58.47 \\
\hline 5 & SXITB3 & 8.00 & 27.00 & 26.00 & 39.00 & 40.58 & 59.42 & 60.44 & 3.57 & 2.59 & 0.49 & 32.91 & 0.79 & 0.46 & 27.23 \\
\hline 6 & SXITB2 & 8.00 & 22.80 & 21.40 & 47.80 & 45.10 & 54.90 & - & - & - & - & - & - & - & - \\
\hline 7 & SXITB1 & 10.00 & 25.00 & 23.00 & 42.00 & 43.28 & 56.72 & 64.34 & 3.21 & 2.55 & 0.78 & 29.12 & 0.64 & 0.44 & 29.44 \\
\hline \multicolumn{16}{|c|}{ Seam-XI bottom } \\
\hline 1 & SXIBB10 & 7.00 & 27.00 & 20.00 & 46.00 & 39.49 & 60.51 & - & - & - & - & - & - & - & - \\
\hline 2 & SXIBB9 & 5.40 & 29.00 & 19.00 & 46.60 & 45.45 & 54.55 & 71.08 & 4.21 & 2.52 & 0.90 & 21.28 & 0.59 & 0.34 & 32.91 \\
\hline 3 & SXIBB8 & 7.00 & 35.40 & 16.00 & 41.60 & 41.15 & 58.85 & - & - & - & - & - & - & - & - \\
\hline 4 & SXIBB7 & 4.50 & 31.10 & 20.00 & 44.40 & 41.41 & 58.59 & 70.75 & 7.74 & 2.16 & 0.97 & 18.39 & 0.85 & 0.20 & 38.21 \\
\hline 5 & SXIBB6 & 7.00 & 30.00 & 21.00 & 42.00 & 39.62 & 60.38 & - & - & - & - & - & - & - & - \\
\hline 6 & SXIBB5 & 10.00 & 29.00 & 16.80 & 44.20 & 41.67 & 58.33 & - & - & - & - & - & - & - & - \\
\hline 7 & SXIBB4 & 8.30 & 31.10 & 16.60 & 44.00 & 41.19 & 58.81 & - & - & - & - & - & - & - & - \\
\hline 8 & SXIBB3 & 7.00 & 30.00 & 20.10 & 42.90 & 45.97 & 54.03 & 73.73 & 5.23 & 1.56 & 1.23 & 18.26 & 1.33 & 0.07 & 55.14 \\
\hline 9 & SXIBB2 & 8.00 & 35.00 & 15.00 & 42.00 & 38.36 & 61.64 & - & - & - & - & - & - & - & - \\
\hline 10 & SXIBB1 & 6.10 & 28.00 & 23.00 & 42.90 & 36.99 & 63.01 & 66.47 & 3.25 & 0.94 & 0.51 & 28.84 & 0.71 & 0.09 & 82.50 \\
\hline \multicolumn{16}{|c|}{ Seam-III } \\
\hline 1 & S3B8 & 5.00 & 28.60 & 15.00 & 51.40 & 35.75 & 64.25 & 78.51 & 4.15 & 2.20 & 0.28 & 14.86 & 0.51 & 0.10 & 41.63 \\
\hline 2 & S3B7 & 6.00 & 32.80 & 10.00 & 51.20 & 39.05 & 60.95 & 75.74 & 3.37 & 0.83 & 0.76 & 19.31 & 0.64 & 0.14 & 106.46 \\
\hline 3 & S3B6 & 4.00 & 33.00 & 12.00 & 51.00 & 39.29 & 60.71 & - & - & - & - & - & - & - & - \\
\hline 4 & S3B5 & 7.00 & 28.50 & 12.00 & 52.50 & 35.19 & 64.81 & - & - & - & - & - & - & - & - \\
\hline 5 & S3B4 & 7.00 & 29.00 & 13.00 & 51.00 & 36.25 & 63.75 & 75.90 & 4.05 & 2.31 & 0.51 & 17.22 & 0.73 & 0.16 & 38.33 \\
\hline 6 & S3B3 & 6.00 & 30.00 & 15.00 & 49.00 & 37.97 & 62.03 & 75.11 & 4.72 & 1.14 & 0.55 & 18.49 & 0.54 & 0.10 & 76.87 \\
\hline 7 & S3B2 & 6.00 & 31.00 & 11.00 & 52.00 & 37.35 & 62.65 & 71.45 & 3.82 & 2.06 & 0.40 & 22.28 & 0.44 & 0.17 & 40.47 \\
\hline 8 & S3B1 & 9.00 & 33.00 & 10.00 & 48.00 & 40.74 & 59.26 & 79.46 & 3.40 & 2.19 & 0.46 & 14.50 & 0.52 & 0.05 & 42.33 \\
\hline
\end{tabular}

$M$ moisture, $V M$ volatile matter, $F C$ fixed carbon, $C$ carbon elemental, $H$ hydrogen elemental, $N$ nitrogen elemental, $S$ sulphur elemental, $O$ oxygen elemental

Meyers and Lallier-Vergés 1999). The $\mathrm{C} / \mathrm{N}$ ratio over 20 is suggestive of terrestrial flora and dominance of higher plants is shown when $\mathrm{C} / \mathrm{N}$ ratios are over 40 (Meyers and Ishiwatari 1993). The investigated samples show the ratios to be over 20 and 40 (Table 4) indicative of input from higher plants.

\section{Rank and maturity}

Volatile matter (d.a.f.) and vitrinite reflectance $\left(R_{\mathrm{om}} \%\right)$ have been used for the determination of rank of the coals. On the basis of volatile matter (d.a.f.), the investigated coals, are high volatile ' $B$ ' to ' $A$ ' sub-bituminous in rank, slightly different from the ranks derived from vitrinite reflectance, which place them under medium volatile bituminous 'B' to 'A' as per ASTM classification (2004).

\section{Rock-eval pyrolysis}

Assessment of organic matter in coal in terms of quality and quantity is a prerequisite for source rock-evaluation (Littke et al. 1989; Gentzis et al. 1993; Cmiel and Fabianska 2004). The rock eval pyrolysis is an established method (Espitalie et al. 1977; Peters 1986; Tyson 1995; Taylor et al. 1998; Vandenbroucke and Largeau 2007) for characterization of organic matter in sediments and their degree of thermal maturity.

The samples show high TOC (between $37.07 \%$ and $68.83 \%$ ) indicating good source rock characteristics. S1 is very low for the coals (between $0.26 \%$ and $1.46 \%$ ) suggesting that they have fair generating potential (Table 5). While S2 is very high (between $57.1 \%$ and $113.2 \%$ ), which is indicative of good generating potential for hydrocarbons. Hydrogen Index (HI) varies from 95 to 
Table 5 Rock-Eval pyrolysis results of the studied samples

\begin{tabular}{lllllllrrrrr}
\hline S1. no. & Sample & Lithology & TOC $(\mathrm{wt} \%)$ & $T_{\max }\left({ }^{\circ} \mathrm{C}\right)$ & $\mathrm{S} 1(\mathrm{mg} / \mathrm{g})$ & $\mathrm{S} 2(\mathrm{mg} / \mathrm{g})$ & $\mathrm{S} 3(\mathrm{mg} / \mathrm{g})$ & HI & OI & PI & TOC/N \\
\hline 1 & SXITB7 & Coal & 47.12 & 421 & 0.37 & 66.96 & 15.96 & 142 & 35 & 0.01 & 47.59 \\
2 & SXITB4 & Coal & 38.73 & 420 & 0.85 & 75.61 & 5.05 & 195 & 13 & 0.01 & 32.00 \\
3 & SXITB1 & Coal & 43.42 & 421 & 0.26 & 57.1 & 15.31 & 132 & 35 & 0.005 & 17.02 \\
4 & SXIBB6 & Coal & 37.07 & 421 & 0.51 & 66.24 & 7.95 & 179 & 21 & 0.01 & 14.71 \\
5 & SXIBB9 & Coal & 55.29 & 421 & 0.46 & 78.92 & 17.62 & 143 & 32 & 0.01 & 21.94 \\
6 & S3B8 & Coal & 68.83 & 420 & 0.44 & 65.37 & 23.16 & 95 & 34 & 0.01 & 31.28 \\
7 & S3B7 & Coal & 50.85 & 424 & 1.40 & 113.22 & 7.17 & 223 & 14 & 0.01 & 61.26 \\
8 & S3B1 & Coal & 55.95 & 422 & 0.40 & 74.63 & 11.1 & 133 & 20 & 0.01 & 25.54 \\
\hline
\end{tabular}

TOC total organic carbon, $H I$ hydrogen index, $O I$ oxygen index, $P I$ production index, $N$ nitrogen

$223 \mathrm{~g} / \mathrm{TOC}$ suggesting that they have potential for gas. $\mathrm{T}_{\max }\left(420-424{ }^{\circ} \mathrm{C}\right)$ of the samples indicate immature organic matter. What emerges from the Rock-Eval pyrolysis investigation is that the coals have low concentration of free hydrocarbons. The amount hydrocarbon generated from pyrolysis experiment is greater than free hydrocarbons $(\mathrm{S} 1>\mathrm{S} 3)$. The TOC content in the samples categorize them as good source rock. The coals are likely to generate gas or oil with progress in maturation. As expected, the production index (PI) is low ranging from .005 to .01 which is related to the free hydrocarbon present in the samples. The thermal maturity of the samples based on Rock Eval parameters such as PI and $T_{\max }$ $\left(417-428^{\circ} \mathrm{C}\right)$ suggest that the samples lie below oil window. Based on $\mathrm{H} / \mathrm{C}$ ratio versus $\mathrm{O} / \mathrm{C}$ ratio (Jones and Edison 1978; Van Krevelen 1993) show that the coals follow the mean evolutionary path of Kerogen Type III (Fig. 9) which is in agreement with the plot of samples on pseudo Van Krevelen diagram (Fig. 10) using Hydrogen index (HI) versus Oxygen Index (OI) and HI versus OI cross plot typify low $\mathrm{HI}$ and moderate OI. The investigated samples capacity remains below the threshold level of hydrocarbon generation.

The relation between Vitrinite (m.m.f. basis) and hydrogen index (Fig. 11a) shows a negative correlation, While, between Liptinite (m.m.f. basis) and Hydrogen Index reveal a positive correlation (Fig. 11b). The Hydrogen index and Oxygen index relation in the coals show that both the contents have a strong negative correlation in the samples (Fig. 11c).

Hydrocarbon generation potential of the coaly source rocks basically belonging to Type-III Kerogen have been widely evaluated (Wilkins and George 2002; Petersen 2006). The results have been more diverse and the rockeval data parameters differ in trends than do the marine and lacustrine source rocks. With examples of coal acting as source rock in the Niger Delta in Nigeria (e.g. Ekweozor et al. 1979); Gippsland (Thomas 1982; Shanmugam 1985); the Beaufort-Mackenzie Delta in Canada (Snowdon and

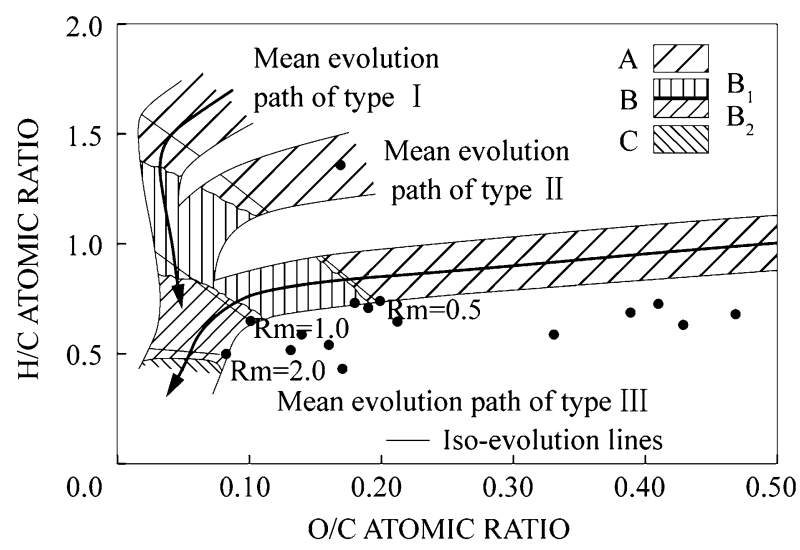

Fig. 9 Thermal evolution pathways of four kerogen types and their micro components based on $\mathrm{H} / \mathrm{C}$ and $\mathrm{O} / \mathrm{C}$ ratios

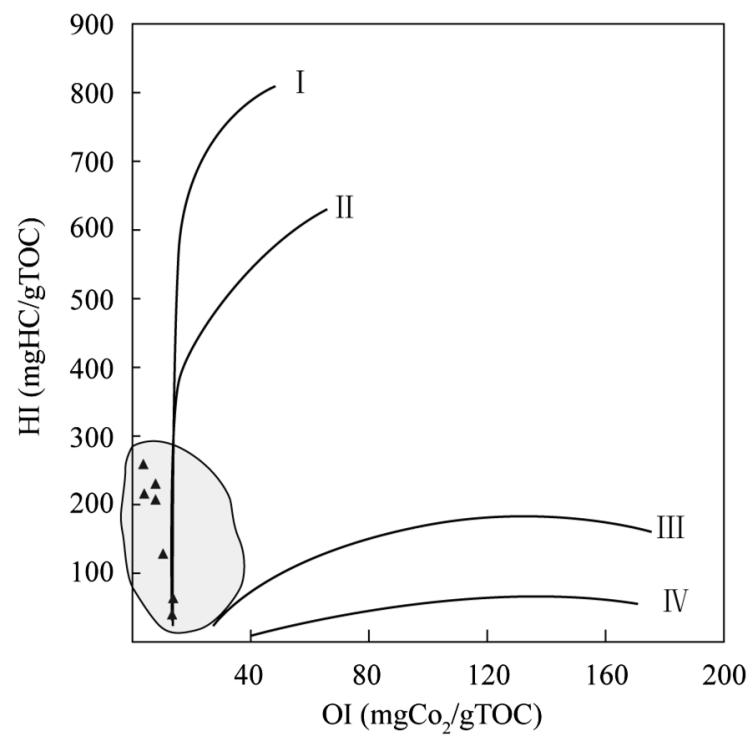

Fig. 10 Van krevelen diagram based on hydrogen index (HI) and oxygen index $(\mathrm{OI})$

Powell 1982); and the Mahakam Delta in Indonesia (e.g. Robinson 1987; Peters et al. 1999), it is evident that the rock-eval data should be used with caution. But in general, 

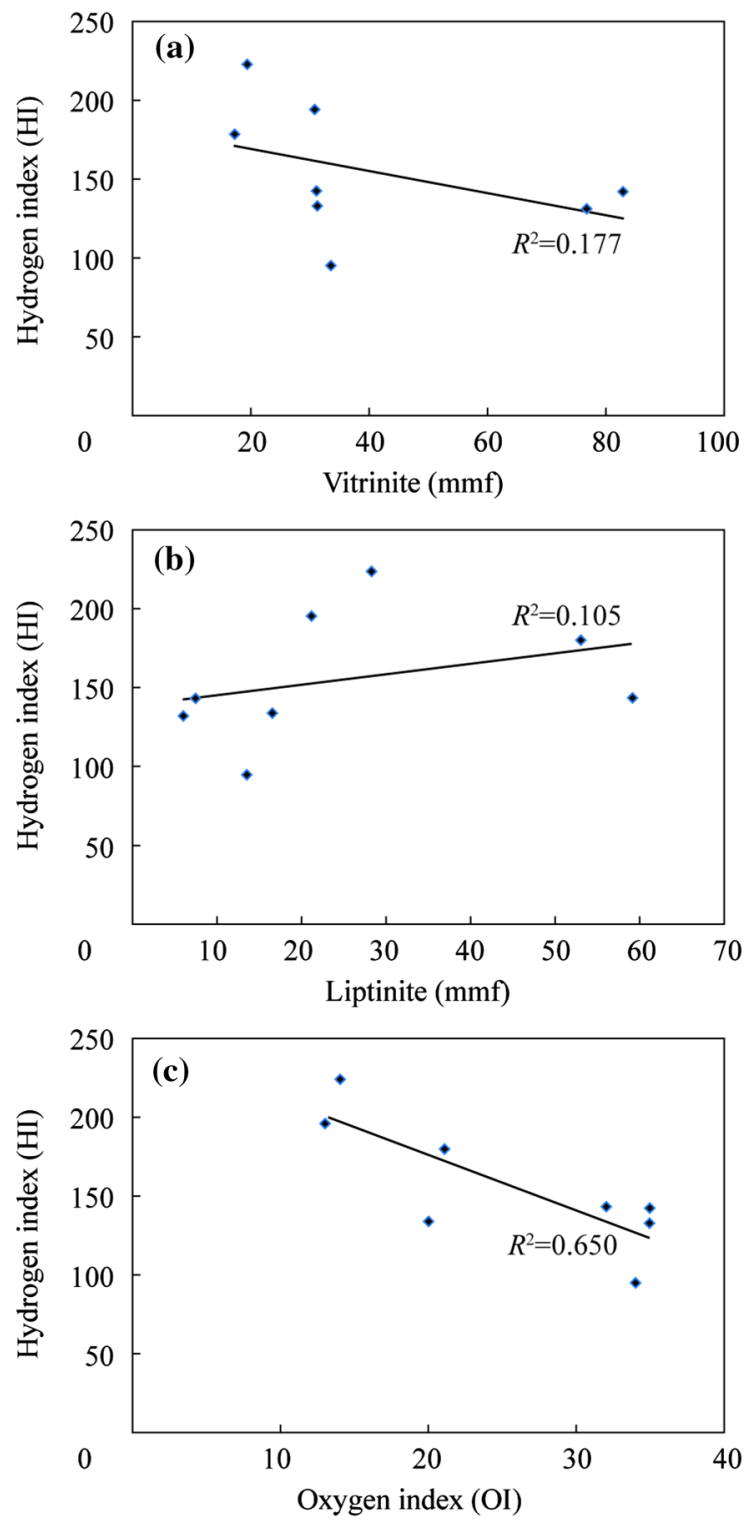

Fig. 11 Hydrogen Index versus vitrinite (m.m.f. basis), liptinite (m.m.f. basis) and Oxygen index (OI)

the generative capacities of Type III have much lower hydrocarbon-generative capacities than do Type II kerogens and, unless they have small inclusions of Type II material, are normally considered to generate mainly gas. Type III kerogens are composed of terrestrial organic material that is lacking in fatty or waxy components. Cellulose and lignin are major contributors and Type III kerogens have high oxygen content because they are formed from lignin, cellulose, phenols, and carbohydrates. The rock-eval and elemental data for example TOC/N ratios range from 27.23 to 106.46 (Table 4). These values reflect that the precursor materials for coal were derived from land plant organic matter (Meyers 1989, 1994; Dumitrescu and Brassell 2006; Bechtel et al. 2007). The samples have low H/C $(<1)$ except sample SXIBB3 which has $\mathrm{H} / \mathrm{C}$ ratio more than one and the samples have relatively high $\mathrm{O} / \mathrm{C}$ atomic ratios $(0.05-0.59)$ typical of type III organic matter (Killops and Killops 2005).

\section{Peat-forming conditions}

The development of the peat or seam can be interpreted from the constitution of the maceral and mineral matter in the seam profile. The clastic partings in the seam are an indication of the termination of the peat development (Shearer et al. 1994). There are several bounding surfaces which appear in the coal seams. The presence of inertinite macerals such as fusinite, semi-fusinite and inertodetrinite indicates peat's exposure to oxidation and fusain bands indicating forest fire (Shearer et al. 1994). There has been a large occurrence of fusain in the investigated coals which are signatures of paleo fires and dry periods in history of peat development.

Hacquebard and Donaldson (1969) propounded a facies diagram based on microlithotype composition for interpretation of depositional environment, later modified by Marchioni (1980), was used in this investigation. According to the diagram, the upper triangle of this double diamond facies model characterizes the bright coal triangle, denoting relatively dry conditions, increasing towards the apex 'terrestrial' (Marchioni 1980). The upper triangle is applicable to coal with $<20 \%$ dull components (D). While the lower triangle is applicable for coals with $>20 \%$ dull components, evolved in the subaquatic conditions (limnic zone) with open moor facies and limno-telmatic zone with forest moor and reed moor facies. The four components of this facies diagrams are:

$$
\begin{aligned}
& \mathrm{A}=\text { Sporoclarite }+ \text { duroclarite }+ \text { vitrinertoliptite } \\
& \mathrm{B}=\text { Fusitoclarite }+ \text { vitrinertite 'I' }+ \text { fusite } \\
& \mathrm{C}=\text { Vitrite }+ \text { clarite 'V' }+ \text { cuticoclarite }+ \text { vitrinertite ' } \mathrm{v} \text { ' } \\
& \mathrm{D}=\text { Clarodurite }+ \text { durite }+ \text { macroite }+ \text { carbominerite }
\end{aligned}
$$

The plots of microlithotype analyses in this facies diagram (Fig. 12) suggest that these coals probably originated in dominantly limno-telmatic environment having floral contributions, characteristic of forest swamps with intermittent hydrological conditions leading to the development of forest moor facies. Teichmuller and Teichmuller (1982) had a different view suggesting that sub-aquatic sedimentation is frequent in the telmatic basins and is very likely that the possibility of overlap of telmatic (terrestrial) and limnic (subaquatic) facies in the forest swamps.

Petrographic indices deduced from the maceral analyses have been in use by the coal petrologists for reconstructing paleoenvironmental conditions of the swamps. Diessel (1965) used gelification index (GI) and tissue preservation index (TPI). 


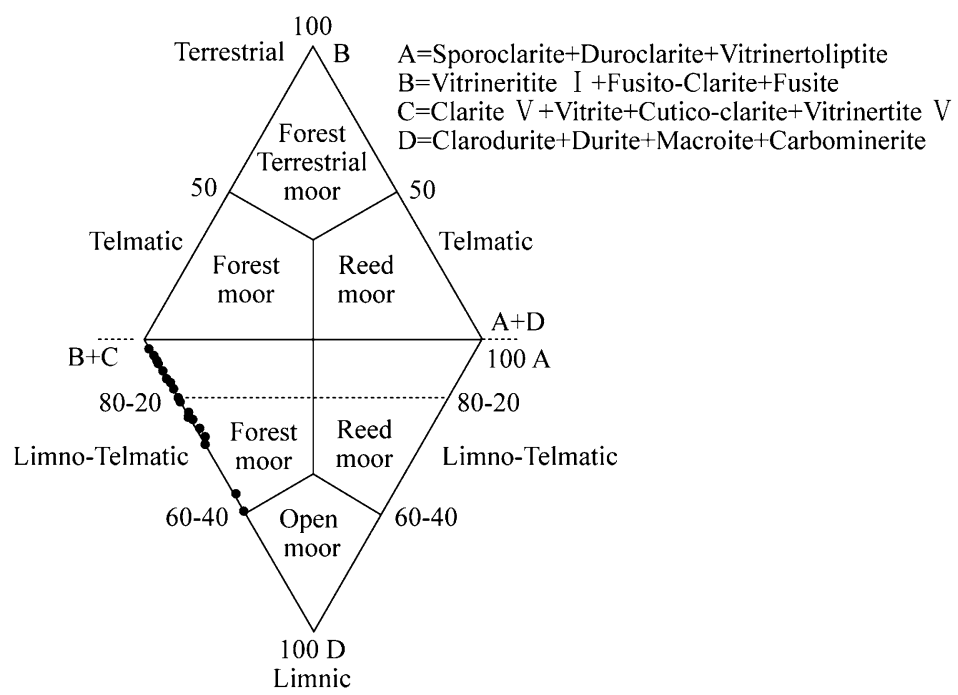

Fig. 12 Microlitotype composition of coals plotted on facies diagram proposed by Hacquebard and Donaldson (1969) and modified (after Marchioni 1980)

The parameter to measure the degree and persistence of wet condition was termed as gelification index (GI) and tissue preservation index (TPI) was a measure of tissue break down and amount of woody plants in the original peat forming assemblages (Lamberson et al. 1991; Alkande et al. 1992; Singh and Shukla 2004; Singh et al. 2013). This scheme was an attempt to throw light on paleofacies, depositional setting and type of mire. GI and TPI were calculated through the following formula:

The maceral composition of coals on this facies diagram suggests that these coals are dominantly terrestrial in origin
Facies model based on quantitative relationships of macerals proposed by Calder et al. (1991) retrieves coal facies on the basis of Ground Water Index (GWI) and Vegetation Index (VI), and the fundamentals therein are very close to Diessel's GI and TPI indices. Teichmuller (1962) and Hacquebard and Donaldson (1969) opined that the water depth in the peat swamp plays an important role affecting the nature of vegetation in the swamp and has a bearing on the mode of preservation of the petrographic entities. The parameters applied in the reconstruction of peat lands (peat land $=$ marsh + swamp) are the degree of groundwater

$$
\begin{aligned}
\mathrm{GI} & =\frac{\text { Vitrinite }+ \text { Macrinite }}{\text { Semifusinite }+ \text { Fusinite }+ \text { Inertodetrinite }} \\
\mathrm{TPI} & =\frac{\text { Telinite }+ \text { Collotelinite }+ \text { Semifusinite }+ \text { Fusinite }+ \text { Desmocollinite }}{\text { Macrrinite }+ \text { Inertodetrinite }+ \text { Vitrodetrinite }+ \text { Corpocollinte }}
\end{aligned}
$$

with high tree density (Fig. 13). According to Diessel (1965) the wet conditions of peat development are characterized by high GI and telovitrinite based high TPI but peat formed in dry conditions gives low GI and low telovitrinite based on TPI. control, relative rain fall (Kalkreuth et al. 1991; Ligouis and Doubinger 1991), changes in ground water level, vegetation, mineral matter content and degree of preservation of maceral precursors (Calder et al. 1991). The GWI and VI are calculated with the help of following formula:

$$
\begin{aligned}
\text { GWI } & =\frac{\text { Gelocollinite }+ \text { Corpocollinite }+ \text { Claymineral }+ \text { Quartz }+ \text { Vitrodetrinite }}{\text { Tellinite }+ \text { Telocollinite }+ \text { Desmocollinite }} \\
V I & =\frac{\text { Telinite }+ \text { Telocolinte }+ \text { Fusinite }+ \text { Semifusinite }+ \text { Secretinite }+ \text { Resinite }}{\text { Desmocolinite }+ \text { Inertodetrinite }+ \text { Alginite }+ \text { Liptodetrinite }+ \text { Cutinite }}
\end{aligned}
$$




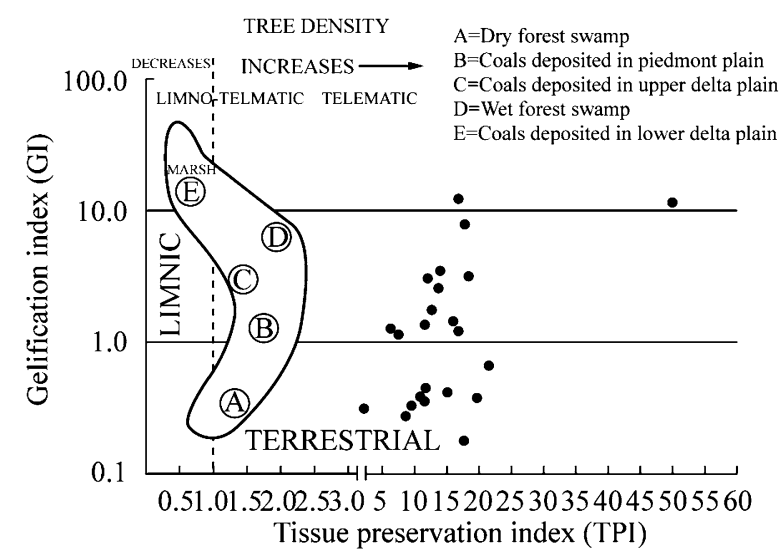

Fig. 13 Coal facies deciphered from the Gelification Index (GI) and Tissue preservation Index (TPI) in relation to depositional setting and type of mire (after Diessel 1965)

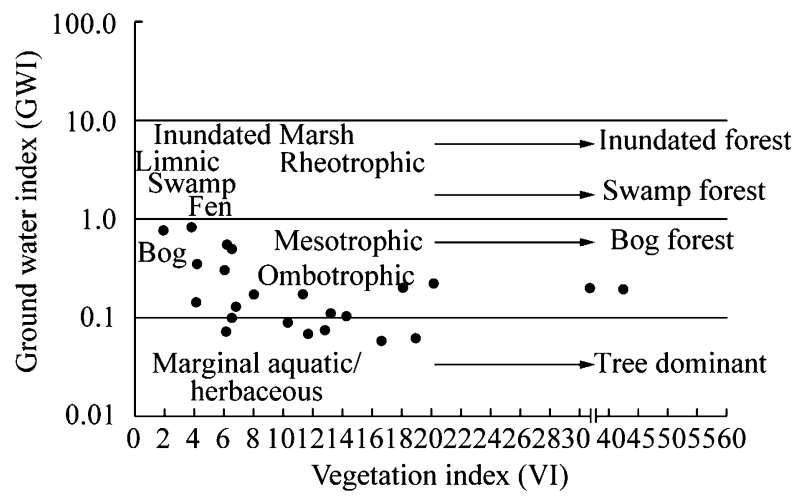

Fig. 14 Palaeoenvironment of mires based on ground water index (GWI) and vegetation index (VI) (after Calder et al. 1991)

Major mire paleoenvironments identified by Calder et al. (1991); Singh et al. (2012a, 2012b) were based on parameters such as limnic (open water marsh), swamp, fen and bog (Fig. 14). Besides making important revelations about hydrological conditions in terms of rheotrophic, mesotrophic and ombrotrophic mires, the Ground Water Index values of coals suggest that these coals evolved as bogs under ombrotrophic to mesotrophic hydrological conditions. The vegetation index values are indicative of preponderance of herbaceous plants in the formation of these coals. In another facies model (Fig. 15), proposed by Singh and Singh (1996), based on maceral and mineral matter content, the data plots of coals suggest the development of peat took place in highly fluctuating alternate oxic and anoxic moor conditions. The coals being comparatively rich in vitrinite indicate their formation in a deeper basin. This variation of depth has also been shown by TPI Index. The plots of coals on a model suggested by Smyth (1979) (Fig. 16), where lacustrine system and lower delta plain is represented by durite + inertite, and

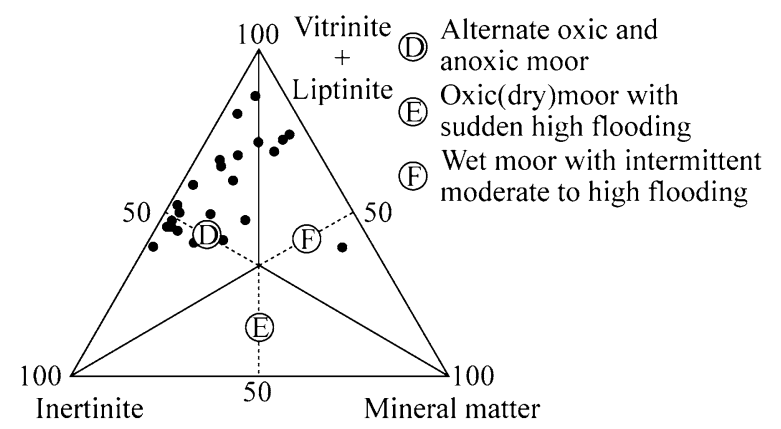

Fig. 15 Depositional condition of coals based on macerals and mineral matter (after Singh and Singh 1996)

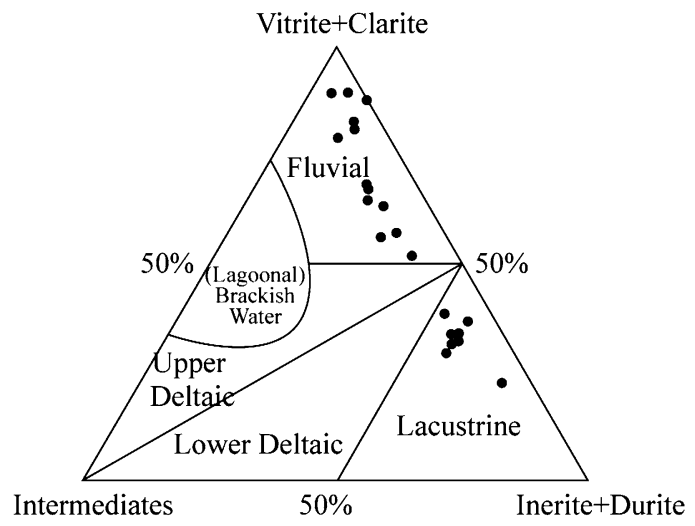

Fig. 16 Environment of coal deposition based on microlithotype composition (modified after Smyth 1979)

vitrite + clarite represents upper deltaic fluvial and lagoonal environments. The delta plain environment is represented where the coal character is intermediate in nature. The samples indicate their deposition under fluviolacustrine environment with the development of upper deltaic and lower deltaic conditions near the fresh water lakes.

\section{Conclusions}

Petrographically, vitrinite group of macerals dominate followed by inertinite and relatively in lesser concentration are macerals of the liptinite group. Among the vitrinites, collotelinite record the highest followed by vitrodetrinite and collodetrinite. In the studied coals, inertinite also has a major presence indicating dry episodes in the development of the peat. Among the microlithotypevitrite followed by inertite, clarite and durite are major entities in the coals. The rank of the coal as per the volatile matter is between sub-bituminous ' $\mathrm{B}$ ' and sub-bituminous ' $\mathrm{A}$ '. Hydrocarbon generation potential is low as indicated by rock-eval pyrolysis. Based on $\mathrm{HI}$ and OI plots and elemental $\mathrm{H} / \mathrm{C}$ and $\mathrm{O} / \mathrm{C}$ ratio, the investigated coals have been characterized as 
kerogen Type III, suggestive of dominantly terrestrial and lacustrine organic matter. The peat development on basis of microlithotype composition suggest their evolution in limno-telmatic zones having floral inputs characteristic of forest moor with intermittent hydrological conditions. The Gelification Index and Tissue Preservation Index are suggestive of terrestrial origin with high tree density. Further, moderately high GI and exceedingly high telovitrinite based TPI along with high ash content are indicative of their origin in intermittent dry forested swamps. The Ground Water Index suggests that these coals have evolved in bogs under ombrotrophic hydrological conditions. The Vegetation Index values are indicative of preponderance of herbaceous plants in the formation of the coals. The plots on a depositional model given by Smyth (1979) indicate their deposition under fluvio-lacustrine control with the development of upper deltaic and lower deltaic conditions near the fresh water lacustrines.

Acknowledgement The research work received financial support from University Grants Commission India, Deutscher Akademischer AustauschDienst, Germany. The author likes to extend heartfelt gratitude to the Head, Department of Geology, Banaras Hindu University and Head, Organic Petrology Lab, TU Bergakademie, Freiberg for providing facilities for research.

Open Access This article is distributed under the terms of the Creative Commons Attribution 4.0 International License (http://crea tivecommons.org/licenses/by/4.0/), which permits unrestricted use, distribution, and reproduction in any medium, provided you give appropriate credit to the original author(s) and the source, provide a link to the Creative Commons license, and indicate if changes were made.

\section{References}

Acharya SK (2000) Prospects and potentiality of coalbed methane $(\mathrm{CBM})$ in India: Present status. Min Geol MI Trans 96(1\&2):15-37

Alkande SO, Hoffknecht A, Erdtmann BD (1992) Rank and petrographic composition of selected Upper Cretaceous and Tertiary coals of southern Nigeria. Int J Coal Geol 20:209-224

American Society for Testing and Materials (ASTM) (2004) Annual book of ASTM Standards, Section 5, Volume 05.06. Gaseous Fuels; Coal and Coke. American Society for Testing and Materials, Philadelphia, PA

Bureau of Indian standards (2003)

Bechtel A, Woszczyk M, Reischenbacher D, Sachsenhofer RF, Gratzer R, Puttmann W, Spychalski W (2007) Biomarkers and geochemical indicators of Holocene environmental changes in coastal Lake Sarbsko (Poland). Org Geochem 38:1112-1131

Calder JH, Gibbling MR, Mukhopadhyay PK (1991) Peat formation in a West Phalian B Piedmont setting, Cumberland Basin, Nova Scotia: Implication for the maceral-based interpretation of rheotrophic and raised paleomires. Bull Soc Geol $\mathrm{Fr}$ 162:283-298

Chakraborti B, Chakraborty S (2001) Triassic floral assemblage from Baronakunda, Raigarh Gondwana basin, Madhya Pradesh; In: Proceedings of the National Seminar on Recent Advances in
Geology of Coal and Lignite Basins of India. Geological Survey of India. Special Publication, vol 54, pp 103-112

Chakraborti B, Ram-Awatar (2006) Inter-relationship of the palynofloral assemblages from Mand Raigarh Coalfield, Chhattisgarh and its significance. Indian Miner 60(3\&4):153-170

Cmiel SR, Fabianska MJ (2004) Geochemical and petrographic properties of some Spitsbergen Coals and dispersed organic matter. Int J Coal Geol 57:77-97

Dasgupta P (2006) Facies characteristics of Talchir Formation, Jharia Basin, India: implications for initiation of Gondwana sedimentation. Sed Geol 185:59-78

Diessel CFK (1965) Correlation of macro-and micropetrography of some new South Wales coals. In: Proceedings of the 8th Commonwealth Mining and Metallurgical Congress, vol 6. Melbourne, Australia, pp 669-677

Dumitrescu M, Brassell SC (2006) Compositional and isotopic characteristics of organic matter for the early Aptian Oceanic Anoxic Event at Shatsky Rise, ODP Leg 198. Palaeogeogr Palaeoclimatol Palaeoecol 235:168-191

Ekweozor CM, Okogun JI, Ekong D, Maxwell J (1979) Preliminary organic geochemical studies of samples from the Niger Delta (Nigeria). I. Analysis of crude oils for triterpanes. Chem Geol 27:11-28

Erik NY (2011) Hydrocarbon generation potential and MiocenePliocene paleoenvironments of the Kangal Basin (Central Anatolia, Turkey). J Asian Earth Sci 42:1146-1162

Espitalie JM, Madec M, Tissot B, Menning JJ, Leplar P (1977) Source rock characterization method for Petroleum Exploration Annual offshore Technology Conference vol 3, pp 439-448

Gentzis T, Goodarzi F, Snowdon LR (1993) Variation of maturity indicators (optical and Rock-Eval) with respect to organic matter type and matrix lithology: an example from Melville Island, Canadian Arctic archipelago. Mar Pet Geol 10:507-513

Goswami S (2008) Marine influence and incursion in the Gondwana basins of Orissa, India: A review. Palaeoworld 17:21-32

Hacquebard PA, Donaldson (1969) In: In: Dapples EC, Hopkins ME (ed) Carboniferous coal deposition associated with flood plain and limnic environments in Nova Scotia. Geological Survey of Canada, Nova Scotia

http://powermin.nic.in/JSP_SERVLETS/internal.jsp. Accessed on 20 Feb 2014

http://coal.nic.in/content/coal-reserves. Accessed on 20 June 2015

Hunt JM (1991) Generation of gas and oil from coal and other terrestrial organic matter. Org Geochem 17:673-680

Hunt JM (1996) Petroleum geochemistry and geology, 2nd edn. Freeman, New York

ICCP (1998) The new vitriniteclaasification (ICCP System 1994). Fuel 77:349-358

ICCP (2001) The new inertinite claasification (ICCP System 1994). Fuel 80:459-471

Jana BN, Bhattachryya AP, Chakraborti B (2002) Permian palynological succession from Mand-Raigarh Coalfield, Chhattisgarh. J Geol Soc India 59:537-546

Jones RW, Edison TA (1978) SEPM Publications In: North FK (ed), Petroleum geology. Alleen and Unwin, Boston

Kalkreuth WD, Marchioni DL, Calder, JH, Lamberson MN, Naylor RD, Paul J (1991) The relationship between coal petrography and depositional environments from selected coal basins in Canada. In: Kalkrueth WD, Bustin RM, Cameron AR (eds), Recent advances in organic petrology and geochemistry. A Symposium Honouring Dr. P. Hacquebard. Int J Coal Geol 19:21-76

Killops SD, KillopsVJ (2005) Introduction to organic geochemistry, 2 edn. Blackwell Publishing, Oxford

Lamberson MN, Bustin RM, Kalkreuth W (1991) Lithotype (maceral) composition and variation as correlated with paleo-wetland 
environments, Gates Formation, Northeastern British Columbia, Canada. Int J Coal Geol 18:87-124

Ligouis B, Doubinger J (1991) Petrology, palynology and depositional environments of the "Grande Couche de Bourran" from the Stephanian Basin of Decazeville, France. Bull Soc Geol Fr 162(2):307-323

Littke R, Horsfield B, Leythaeuser D (1989) Hydrocarbon distribution in coals and dispersed organic matter of different maceral compositions and maturities. Geol Rundsch 78:391-410

Marchioni DL (1980) Petrography and depositional environments of the Liddel seam, Upper Hunter Valley, New South Wales. Int J Coal Geol 1:35-61

Medlicot HB, Blanford WT (1879) A manual of geology of India. Geological Survey of India, London, vol 1, pp 1-144

Meyers PA (1989) Sources and deposition of organic matter in Cretaceous passive margin deep-sea sediments: a synthesis of organic geochemical studies from Deep Sea Drilling Project Site 603 outer Hatteras Rise. Mar Pet Geol 6:182-189

Meyers PA (1994) Preservation of source identification of sedimentary organic matter during and after deposition. Chem Geol 144:289-302

Meyers PA, Ishiwatari R (1993) Lacustrine organic geochemistry-an overview of indicators of organic matter sources and diagenesis in lake sediments. Org Geochem 20:867-900

Meyers PA, Lallier-Vergés E (1999) Lacustrine sedimentary organic matter records of Late Quaternary paleoclimates. J Paleolimnol $21: 345-372$

Ministry of Coal (2015) http://coal.nic.in/content/coal-reserves. Accessed 20 June 2015

Ministry of Power (2014) http://powermin.nic.in/JSP_SERVLETS/ internal.jsp. Accessed $20 \mathrm{Feb} 2014$

Mukhopadhyay G, Mukhopadhyay SK, Roychowdhury Mandparui PK (2010) Stratigraphic correlation between different Gondwana basins of India. J Geol Soc India 76:251-266

Murthy S, Ram Awatar, Gautam S (2014) Palynostratigraphy of Permian succession in the Mand-Raigarh Coalfield, Chhattisgarh, India and phytogeographical provincialism. J Earth Syst Sci 8:1879-1893

Peter KE (1986) Guidelines for evaluating petroleum source rock using Programmed pyrolysis. Am Assoc Pet Geol 70:318-329

Peters KE, Snedden JW, Sulaeman A, Sarg JF, Enrico RJ (1999) A new geochemical-sequence stratigraphic model for the Mahakam Delta and Makassar slope, Kalimantan Indonesia. Abstract of AAPG International Conference and Exhibition. Bull Am Assoc Pet Geol 83:1332-1333

Petersen HI (2006) The petroleum generation potential and effective oil window of humic coals related to coal composition and age. Int J Coal Geol 67:221-248

Raja Rao CS (1983) Coal resources of Madhya Pradesh, Jammu and Kashmir Coalfields of India, Mand-Raigarh Coalfield, Madhya Pradesh. Bull Geol Surv India 45(3):12-20

Ram-Awatar (2007) Palynostratigraphy and depositional environment of Lower Gondwana sediments in Raigarh Basin, Chhattisgarh, India. In: Sinha DK (ed), Cropalaeontology: application in stratigraphy and Palaeoceanography, pp 71-79

Robinson KM (1987) An overview of source rocks and oils in Indonesia. In: Proceedings of the 16th Indonesian Petroleum Association, pp 97-122

Shanmugam G (1985) Significance of coniferous rain forests and related organic matter in generating commercial quantities of oil, Gippsland Basin. Bull Am Assoc Pet Geol 69:1241-1254
Shearer JC, Staub JR, Moore TA (1994) The conundrum of coal bed thickness: a theory for stacked mire sequences. J Geol 102:611-617

Singh KJ, Goswami S, Chandra S (2007). Occurrence of cordaitales from lower Gondwana sediments of Ib-River coalfield, Orissa, India. An Indian scenario. J Asian Earth Sci 29:666-684

Singh PK, Singh MP, Singh AK, Arora M (2010) Petrographic characteristics of coal from the Lati formation, Tarakan basin, East Kalimantan, Indonesia. Int J Coal Geol 81:109-116

Singh AK, Banerjee PK, Singh PK, Das A (2015) Study of washability characteristics of coals from seam-IX of Jamadoba Colliery of the Jharia basin, India. Energy Explor Exploit 33(2):181-202

Singh MP, Shukla RR (2004) Petrography characteristics and depositional conditions of Permian coals of Pench, Kanhan, and Tawa Valley Coalfields of Satpura Basin, Madhya Pradesh, India. Int J Coal Geol 59:209-243

Singh MP, Singh PK (1996) Petrographic characterization and evolution of the Permian coal deposits of the Rajmahal Basin, Bihar, India. Int J Coal Geol 29:93-118

Singh PK, Singh MP, Singh AK, Naik AS (2012a) Petrographic and geochemical characterization of coals from Tiru valley, Nagaland, NE, India. Energy Explor Exploit 30(2):171-192

Singh PK, Singh MP, Singh AK, Naik AS, Singh VK, Rajak PK (2012b) Petrological and geochemical investigations of Rajpardi lignite deposit, Gujrat, India. Energy Explor Exploit 30(1):1-18

Singh AK, Singh MP, Singh PK (2013) Petrological investigations of Oligocene coals from foreland basin of north east India. Energy Explor Exploit 31(6):909-936

Smyth M (1979) Hydrocarbon generation in the Fly Lake, Brolga area of the Cooper basin. J Aust Pet Assoc 19:108-114

Snowdon LR, Powell TG (1982) Immature oil and condensatesmodification of hydrocarbon generation model for terrestrial organic matter. Bull Am Assoc Pet Geol 66:1422-1426

Stach E, Mackrowsky M-T, Teichmuller M, Taylor GH, Chandra D, Teichmuller R (1985) Stach's textbook of coal petrology, 3rd edn. Gebruder Borntraeger, Berlin

Taylor GH, Teichmüller M, Davies A, Diessel CFK, Littke R, Robert P (1998) Organic petrology. Gebrüder Borntraeger, Berlin

Teichmuller M (1962) Die Genese der Kohle. In: C.R. 4th Congress International Stratigrafie et Geologie Carbonifere (Heerlen, 1958). 3:699-722

Teichmuller M, Teichmuller R (1982) The geological basis of coal formation, In : Stach E, Mackowsky M-T, Teichmuller M, Taylor GH, Chandra D, Teichmuller R (eds), Stach's text book of coal petrology. Gebruder Borntraeger, Stuttgart, pp 5-82

Thomas BM (1982) Land plant source rocks for oil and their significance in Australian basins. APEA J 22:166-178

Tissot B, Welte DH (1984) Petroleum formation and occurrence. Springer Verlag, New York

Tyson RV (1995) Sedimentary organic matter. organic facies and palynofacies. Chapman and Hall, London

Van Krevelen DW (1993) Coal: typology-chemistry-physicsconstitution. Elsevier, New York

Vandenbroucke M, Largeau C (2007) Kerogen origin, evolution and structure. Org Geochem 38:719-833

Wilkins RWT, George SC (2002) Coal as a source rock for oil: a review. Int J Coal Geol 50:317-361 